\title{
A Framework to Improve Lean Implementation by review leveraging aspects of Organizational Culture: The Case of Saudi Arabia
}

\author{
Abdullah A Alkhoraif*1, Patrick McLaughlin 2 and Hamad Rashid 3
}

\author{
Abdullah A Alkhoraif*1 \\ Manufacturing Department, \\ School of Aerospace, Transport and Manufacturing, \\ Cranfield University, \\ Cranfield, Bedfordshire, \\ MK43 0AL, UK \\ Email: kriyf@me.com \\ *Corresponding author \\ Patrick McLaughlin 2 \\ Manufacturing Department, \\ School of Aerospace, Transport and Manufacturing, \\ Cranfield University, \\ Cranfield, Bedfordshire, \\ MK43 0AL, UK \\ Email:p.mclaughlin@cranfield.ac.uk
}

\author{
Hamad Rashid 3 \\ Assistant Professor \\ College of Engineering \\ University Of Sharjah \\ Email: hamad.rashid@sharjah.ac.ae
}




\section{Biographical notes:}

Abdullah Alkhoraif is a PhD Researcher Assistant at the School of Aerospace Transportation and Manufacturing, Cranfield University. He holds BEng Engineering and Business and MSc Engineering Project Management form the Bournemouth University. Recently, he published two books in The Process of Quality Material Selection and Contractual and Sub-Contractual Risks: Project Management Perspective'. He was involved in oil industry for ten years. This research presented in this article is a part of the research project of A Framework to Improve Lean Implementation by Leveraging Organisational Culture.

Patrick McLaughlin holds CEng, FIET, FIMechE, FHEA, MSc from the School of Aerospace Transportation and Manufacturing, Cranfield University. He is a Chartered Engineer and EurIng. He is a Fellow of both the Institution of Mechanical Engineers and the Institution of Engineering and Technology, as well as a Fellow of the Higher Education Academy. He has an MSc in Industrial Engineering and Production Management and a Doctorate in Business Administration (DBA), both from the Cranfield. He has worked at director level in manufacturing operations for over twenty years, and has been responsible for several plant-wide lean manufacturing implementations.

Hamad Rashid, My current activities include teaching and conducting research in the field of safety and accident investigation within safety-critical industries. Recently I conducted a research that developed an Aviation Safety Monitoring Process which works to proactively prevent aviation accidents and incidents that could be induced by maintenance and other human factors issues. Another research that I recently finalized was funded by EASA. It looked on helicopter main gearbox oil loss optimisation. I have had a career within various sectors of aviation industry. I was graduated as an Aeronautical Engineer (BSc.) 1985-1991, and then got an MSc in Rockets Engines Internal Ballistics in 2000. I worked as a licensed helicopter maintenance engineer in Bell 212/205, Puma 330-all versions, and Mi-24D/V during the period 1991 to 1997, and then worked as a university lecturer in aeronautics, aviation management, and mechanical engineering 1997 to 2003. I then worked as an aviation quality inspector for the period 2003 to 2005, after which I got my PhD in aviation safety, namely: 'Human factors effects in aviation maintenance' at Cranfield University in 2010. 


\title{
A Framework to Improve Lean Implementation by review leveraging aspects of Organizational Culture: The Case of Saudi Arabia
}

\begin{abstract}
Implementing Lean into manufacturing small and medium enterprises faces difficulties, whereas it is more likely to be implemented successfully in larger companies, which then gain the advantages of Lean systems. In addition, Organizational culture is one of the most important factors to focus on to facilitate the implementation of Lean within Saudi Arabian manufacturing. Thus, more research that focuses on Lean implementation in SMEs are needed. This article focuses on contributing to develop a framework to improve Lean Implementation into small and medium enterprise manufacturing organisations in Saudi Arabia by leveraging aspects of Organizational Culture. Qualitative research is confirmed to be useful for uncovering such insider views. The thesis will be based on qualitative and grounded theory inside action research with and an inductive approach. Action research tends to be used for prompting conscious change within a somewhat controlled environment. The data collection generally employed to study culture consist of; semi structured interviews, observation and focus groups. A framework by identifying suitable interventions to facilitate lean culture. A series of interventions developed with participants. These interventions permitted a framework for SMEs to be developed. A plan of linked interventions designed to develop aspects of lean culture forms the output of phase three. The planned interventions for SMEs are should take place together as a series of interlinked interventions. The interventions come from two sources literature review and data gathering. The contributions of this study are threefold: First, there has been no previous framework of Lean implementation in SMEs manufacturing sector. In addition, it also contributes to knowledge about the failure of lean implementation. Concerning aspects of organizational culture that facilitate lean implementation. This knowledge is transdisciplinary and adds to the domains of lean implementation, organizational culture and lean culture. Finally, it supports the academic society with scheme for proposal future research.
\end{abstract}

Keywords: Lean manufacturing; Lean implementation (LI); Grounded theory; Organizational culture (OC); Small and Medium Enterprises (SMEs); King of Saudi Arabia (KSA) 


\section{Introduction}

Organizational culture is one of the critical factors that determine the success of Lean implementation within SMEs (Achanga et al., 2006). The success of Lean implementation will not just be based on applications, tools and techniques, but also on the top managements' involvement, leadership and Organizational culture (Jadhav, et al., 2014). Culture is the key factor to making the changes for Lean implementation (Pakdil and Leonard, 2015a). Lack of research regarding the critical factor of Organizational culture related to Lean implementation (Pakdil and Leonard, 2015a). Lack of knowledge and difficulties in implementing Lean in the Middle Eastern and Gulf countries, but also and increasing concern of Lean implementation in SMEs, (Al-najem, 2014). Focusing on sustaining Lean Implementation is much more demand than cost reduction (Gupta, Sharma and Sunder M., 2016). There is a clear dearth research of Lean implementation for SMEs in developing countries( $\mathrm{Hu}$ et al., 2015). Organizational culture contributes to a successful implementation of lean initiatives and sustainable, proactive and improvement as the main enablers of lean (Rymaszewska, 2017). These inhibiting factors, and indeed those factors that encourage this behaviour can be graphically displayed and tabulated, allowing deeper analysis of each, to find its roots and, where necessary, remove it from the company culture (Hietschold et al.,2014).

Implementing Lean into manufacturing small and medium enterprises faces difficulties, whereas it is more likely to be implemented successfully in larger companies, which then gain the advantages of Lean systems (Karim et al., 2011). Moreover, the culture of an organisation plays a vital role for managers facing the challenge to change that culture (Graham-jones and Muhareb, 2015). It is necessary to have a feasible Lean framework to assist SMEs to successfully implement Lean (Pingyu and Yu, 2010). For the purpose of this paper SMEs refer to organisations with fewer than 250 employees where European Commission definition adopted, (European Commission ,2011). In a country, such as Saudi Arabia, SMEs firms face more challenging and difficulties regarding implementing Lean (Karim et al., 2011). Saudi Arabia's economy has depended on oil and gas resources, forcing the government to find new non-oil sources. According to the IMF (Alshahrani and Alsadiq, 2014), the Kingdom of Saudi Arabia is regarded as a dominant economic force within the Middle East and North Africa region (MENA). According to MODON (Saudi Industrial Property Authority, 2015), Saudi Government has set up clusters in various regions of the Kingdom, and right now manages over than 32 existing and underdevelopment cities . In addition, there are cities under planning and designing, the number of the industrial cities shall reach 40 cities with more than 160 
million square meters of developed industrial lands. There are more than 3,000 factories in the existing industrial cities with investments exceeding 250 billion riyals, and more than 300,000 employees. Moreover, 2000 factories will be built for SMEs. Also, In addition, to increase the private sector's contribution from $40 \%$ to $65 \%$ of GDP with rising the share of non-oil exports in non-oil GDP from $16 \%$ to $50 \%$ (Government, 2015). It had come to the researcher knowledge during career and studies that the success of 'Lean' especially among SMEs in Saudi had been highly unsuccessful (Karim et al., 2011; Zargun and Al-Ashaab, 2013; Alnajem, 2014; Albliwi et al., 2017). Organizational culture is one of the most important factors to focus on to facilitate the implementation of Lean within Saudi Arabian manufacturing (Karim and Arif-Uz-Zaman, 2013). The main aim of this research is to develop an organizational culture framework to facilitate Lean implementation before adopting the Lean system. According to Karim et al., (2011), the most important factor that affects the implementation of Lean is the organisation's culture. It has been observed that the appropriate Lean culture enhances the pace of the growth and keeps the firm competitive, (Pooyan, et al.,2014).

The aim of this research is to develop a framework to improve Lean Implementation into small and medium enterprise manufacturing organisations in Saudi Arabia by leveraging aspects of Organizational Culture. The objectives of this project are:

1. To analyses Organizational culture enablers and inhibitors of Lean implementation, through a literature review.

2. To investigate, via a field study, the Organizational culture enablers and inhibitors for Lean in Saudi Arabian SMEs in the manufacturing sector.

3. To develop a framework to develop an Organizational culture that supports Lean implementation within Saudi Arabian manufacturing SMEs.

4. To validate the developed framework.

The framework will be designed for SMEs, but it will be built at a generic scale to suit other cases as well. The framework should have as few size constraints as possible, and to create it there will be a need to discover as many inhibiting factors as possible. These inhibiting factors, and indeed those factors that encourage this behaviour can be graphically displayed and tabulated, allowing deeper analysis of each, to find its roots and, where necessary, remove it from the company culture (Hietschold et al.,2014). The research question is formulated as" What aspects of Organizational culture facilitate Lean implementation in manufacturing small 
and medium enterprises and how can these aspects be leveraged to improve Lean implementation?" the research question is broken down into the following sub-questions:

1. What are the Organizational culture enablers and inhibitors to Lean Implementation in small and medium sized manufacturing firms?

2. What are the interventions of organizational culture that can improve Lean adoption in KSA?

\section{Literature review}

\subsection{Lean Philosophy}

Lean is defined and interpreted in different ways, and according to Shah and Ward (2007) Lean has been identified as having four approaches; 1 . As an operational philosophy 'leanness' 2. A strategic philosophy, 'Lean thinking' 3. An operational practice 'tool box Lean' and a strategic practice 'becoming Lean', (Shah and Ward, 2007). The definition of Lean provided by (Corbett, 2007) emphasises on Lean as an integral part of the entire organisation, essentially pointing to Lean as being considered more of a philosophy than just a tool or process. This is further supported by Womack and Jones, (2003) who suggest that Lean is becoming understood as more than just production, but an all-encompassing business ideology which incorporates all aspects of value streams as opposed to individual production processes. According to Bhamu and Singh Sangwan, (2014b) Lean provides a methodology by which organisations can significantly improve their responsiveness to customers while decreasing and managing costs and waste in supply and operational procedures. The following Table 1 presents various definitions of Lean.

\section{Table 1 Definitions of Lean}

Overall increased competition and a more globalised market place have led to stiffer competition with greater demands on businesses to succeed. Regarding demand, customers are presented with a great range of products and thus are growing more assertive and looking for greater value. Organisations can respond to this by improving their understanding of aspects valued by customers and exercising improvements in operations to deliver this, (Hu et al., 2015). Thus, many companies have turned towards Lean to help fulfil this challenge. At the heart of Lean is being highly responsive to the needs of customers, while constantly looking to improve waste and cost management, (Hu et al., 2015). An interesting notion to consider in the definition provided above is listing the inclusion of pursuit of improvement with employee involvement, (Allen and Meyer, 1993). One might consider that employee involvement is also 
somewhat dependent on the (OC) of the company, (Angelis et al., 2011). Also, the autonomy given to employees and the existence of two way communication within the business, (Alstrup, 2000).

When looking at Lean from a holistic perspective it is considered to greatly encourage organizational learning,(Womack, Jones and Roos, 1990). It has been suggested that implementing Lean systems sets benchmarks enabling the measurement of performance. However, this is greatly dependent on the type of Lean system design, (Crofton and Dale, 1996). A study conducted in Volvo's Uddevalla automobile plant in Sweden found that 1 learning as much as others, (Adler and Cole, 1995). They suggest that the NUMMI (New United Motor Manufacturing, Inc.) plant in California, a joint venture between GM Motors and Toyota outperformed Uddevalla in terms of performance. This was attributed to the ability to better knowledge sharing compared at NUMMI compared to Uddevalla which gained deeper knowledge which was kept within tight teams, (Adler and Cole, 1995).

Organizational learning can be described as ways in which a company will seek to maintain and ameliorate their competitiveness, productivity and innovation meeting external environmental demands, resulting in a continued competitive advantage, (Dodgson, 1993). The link between Lean and organizational learning is made evident in an experiment with Toyota Motor Corporation and their joint venture with General Motors which discovered that Lean designs were characterised with rather short cycle times and a higher level of standardisation, (Berger, 1997). Therefore, it was apparently easier for employees to pick out issues and create improvements and solve problems,(Crossan, Lane and White, 1999).

Another aspect central to Lean which was mentioned in the definition above is that of waste elimination. However, an aspect of Lean which is sometimes counter intuitive is that this process of waste elimination lessens the resources often allocated for contingency situations creating a somewhat more fragile system, (Crofton and Dale, 1996). This would then rely more heavily on the ability of the employees to react swiftly to deal with malfunctions and smooth out any delays. This concept might be more difficult for cultures which tend to be more risk averse,(Browning and Heath, 2009). However, consistency is even more important in this case and employees must abide by a standardised process when undertaking production tasks. The continuous process improvement is however greatly reliant on the pro-activeness of the employees, (Cameron, 1994). Workers are given more autonomy in quality checking at the source rather than an entire extra operation for the same task. This is also considered to enhance 
employee accountability, critical thinking and empowerment which should be facilitated by (OC). Studies conducted by Whitfield and Pool (1997), MacDuffie (1997), Kochan et al. (1997) and Vidal (2007) have researched human resource practices which would help to encourage productiveness and voluntary participation from employees for the purpose of Lean systems.

Dombrowski, et al. (2010) suggests that Lean includes the following important areas; visual management, workplace organisation, $5 \mathrm{~s}$ and process standardisation, continuous improvement, total quality management and total productive maintenance, just in time and production levelling. Rymaszewska (2014) considers it important to organise the components of the list into two schools of thought, one which provides a holistic view of Lean emphasising Lean as not just tools, but as a philosophy. The other is that Lean should be considered as an addition to current methods employed by manufacturers which is essentially opposite to the holistic view.

\section{Lean as a holistic view}

In relation to Lean and a holistic view school of thought, Basin and Burcher (2006) Lean should be seen as a journey. This notion compliments the original view of kaizen, the Japanese philosophy advocating small improvements made incrementally over time. It is also suggested that standardisation is another key in realising the benefits of continuous improvement thus achieving long term improvement, (Wittenberg, 1994). This is further reinforced by Liker (1997) who emphasises the importance of having a long term orientation in relation to Lean.

\section{Lean as an additional tool}

However, arguments against this holistic view suggest that in pursuit of 'kaizen' and eradicating waste also caused Japan to land in a situation of 'gridlock' in which factories were needing just in time (JIT) inventories and there was a not enough suitable workers nor capital for investment, (Cusumano, 1994). According to Cooney (2002), external factors particularly affecting JIT can be problematic as production should be levelled across the entire supply chain. In addition to this, he highlights the importance to still consider political and social forces, economic conditions and industry factors when implementing Lean, (Cooney, 2002).However, Lewis (2000) suggests that each company should have their own individual Lean development path. He suggests that Lean does not need to be viewed as an all-in or nothing approach, but he advocates that companies should carefully consider aspects such as the market in which they operate in, technological factors and supply chain, (Lewis, 2000). 
James-Moore and Gibbons (1997) suggests that companies with very differentiated and low volume and very little repetition will more likely need to modify Lean methods or consider a completely different approach. Lean's ability for cost reduction and improved flexibility is key to providing a company with a competitive advantage despite debates surrounding Lean as a holistic view or addition to current methods,(Im and Lee, 1989; Lathin et al., 2001; Narasimhan, Kull and Nahm, 2012) As continuous improvement and Lean were originated in Japan in terms of waste, the Japanese refer to Muda, Mura and Muri. Mud is considered a process which does not add any value. The mud wastes were originally identified by Aiichi Ohno from Toyota. Muda waste tends to include the following categories; transport, inventory motion, waiting, overproduction, over-processing defects, talent and resources. Many Lean initiatives often do not go past the stage of identifying Muda. Mura refers to unevenness which relates to production smoothing in Lean operations. Muri refers to overburdening and putting extra stress on operations and workers. Lean aims to eradicate all different types of waste and inefficiency from the organisation,(Hines, Holweg and Rich, 2004).

\subsection{Organizational Culture}

National culture and corporate or OC share some overlaps due to the behaviour commonly held by the members of the company are also members of the same national culture, (Schein, 1984). Goldstein (1957) says that neither the nominal definition of Culture nor the synoptically definition is much help when trying to grasp the meaning of a term with so many variables:

"Definitions... are usually intended to serve one or another of three distinct aims. Of these, the first [nominal definition] may be useful, the second [synoptical definition] is rather futile, and the third [essential definition] entirely pernicious" (Goldstein, 1957, p. 1075).

Philosophers have suggested that culture is primarily defined by language (Lazăr, 2010), but corporations do not have a 'language' - although efforts to create one have been made (Fredriksson,et al. 2006). Although we live in an increasingly globalised world(Held and McGrew, 2000), national and local culture still has a large influence on the way that businesses are run and operate. According to Davis (1985) culture is defined as, The pattern of shared beliefs and values that give members of an institution meaning, and provide with the rules for behaviour in their organisation," (Sun, 2008, p 138). Cross-cultural management is steadily growing (Brannen, 2015) but the differences between East and West, North and South (Lundestad, 1997) are still essential differences in business. The culture of the KSA is Islamic, and this affects the regional economy (Kuran, 1993; Black, 2011) at a very basic or 
fundamental level. In addition, working hours vary in different cultures and climates, and the Islamic culture of prayer breaks was unimaginable in a Western Christian culture (The Telegraph, 2012). Even apparently obvious words, like "teamwork" also can have different meanings in different cultures (Gibson and Zellmer-Bruhn, 2001), so that an American management manual or approach could be considered in a very different way within the KSA; essentially, culture is relative (Tilley, 2000). Companies which operate internationally need to overcome the differences in order to communicate (Wood, 2011), but this will never be easy in a world where even 'Human Rights' have different cultural connotations (Cruft, 2005). This is why Halliday (2000) suggests that, in business, global governance will always encounter endless difficulties, and why terms like 'Corporate Social Responsibility' (CSR) (Burke and Logsdon, 1996), have such broad terms of reference; trying to reconcile these things with local or national culture is an art. Studying culture helps to explain many outcomes and it serves as a reminder that the contrasts in people's behaviour are often attributed to cultural differences.

According to Hofstede et al,(1991) culture influences the way in which people behave so similarly it is important to understand the culture of an organisation. Podrug (2011) suggest that a person's decision making process is dependent on their cultural background according to what is considered 'the right way' highlighting the importance of national culture on OC, (Podrug, 2011). According to Francesco and Gold, (2005) success in the current day's economy is heavily reliant on understanding cultural values and their influence on organisations and the behaviours that occur within them. According to a study conducted by Podrug (2011) a positive correlation was discovered between national culture and the decision-making styles of leaders in organisations. According to Newman and Nollen (1996) the idea of universal human resource practices has been challenged, as policies which work well in one country do not necessarily have the same effect in another. Furthermore, according to Schneider and De Meyer, (1991) national cultures influence strategic decision making and adopted styles of leadership. Countries with a higher power distance scores according to Hofstede's cultural dimensions are more likely to accept feedback without disagreement or contesting the ideas from superiors than those with a lower power distance score, (Hoftstede, 1980). This also has an impact on two way communication flows within the organisation impacted by national culture, (Dartey-Baah, 2013). It has also been discovered that collectivist cultures favour group based training as opposed to one on one training, (Dartey-Baah, 2013). It is recommended that to experience success, policies need to fit with the local cultural context, (Dartey-Baah, 2013). 


\section{Methodology}

Qualitative research is confirmed to be useful for uncovering such insider views, (Corbin and Strauss, 1990).The research will be based on qualitative and grounded theory inside action research with and an inductive approach. Action research tends to be used for prompting conscious change within a somewhat controlled environment, (Collis and Hussey, 2013). In this approach the participants and the researcher collaborate on a problem to find a solution, (Coghlan and Brannick, 2014). This is an inquiry mode generally utilised to help solve organizational issues by dealing with those experiencing the problems, (Ibrahim, 2013). Some main weaknesses associated with action research is the assumption that the behaviour of a person is only able to be changed by testing them and moreover, it tends to require set timelines and is usually expensive to conduct over the full research period, (Fisher, 2007). Grounded theory is a research methodology which aims to create a theory from data which has been systematically researched and analysed, (Strauss, 1987). This methodology was founded originally by (Glaser and Strauss, 1967). According to (Golden-Biddle and Locke, 2007). Grounded theory has been the most vastly utilised qualitative methodology in social science research. Its popularity can be attributed to; firstly, its suitability for developing new theory or new insights form old theory. Secondly, it generates theory which stems from what the research participants consider important Finally, it is able to expose micro-management processes in complex situations and environments, (Locke, 2001). Goulding (1998) suggests grounded theory is particularly useful for making new discoveries thus its usefulness for theory generation. Furthermore, Locke (2001) and Goulding (2005) also consider grounded theory as useful where there is a clear lack of integrated theory in an area of literature. The main feature of this approach is to develop aspects which highlight the data and develop the themes to create a framework, (Silverman, 2006).

Due to the nature of the topic requiring the exploration of culture it is beneficial to utilize qualitative research. An inductive approach enables the researcher to become fully engaged within the research environment thus improving the understanding of the culture being studied, facilitating a more insider's view of the culture, (Walker and Myrick, 2006). Furthermore, it is important to note that most methodologies require extensive literature reviews to inform the research and identify the research question as most research methodology is conducted with a deductive approach, (Dick, 2006). In contrast, grounded theory being inductive ends with a theory as opposed to beginning with a hypothesis and instead is used as a method for reviewing literature, (Trochim and Donnelly, 2001). Hence why research questions and hypotheses are made redundant in grounded theory so, literature is generally used as a comparator, (Dick, 2006). Data analysis in qualitative research deals with words, and the meanings implied by them, (Miles and Huberman, 1994). The analysis of the information gathered is done by discovering aspects and their interrelationships, simultaneous and concurrent data and alongside constant comparison methods. The program utilised for this is NVIVO software for coding. 
The data collection generally employed to study culture consist of; semi structured interviews, observation and focus groups. Focus groups is tool for revealing cultural assumptions and according to Schein, "because the group provides the stimulus to bring out what is ordinarily hidden" (Schein, 1985). Semi structured interviews are often utilised to help expose culturally based values, (Patton, 2014). The key here is, the researcher should not introduce cultural values, but instead using open ended questions and the insider's language, they evoke responses revealing the aspects of everyday life in that cultural setting, (Creswell, 2013). It is important for the researcher to be conscious of their own biases and influences in the information gathering process, (Patton, 2014). It is important however, for the assisting analysts to also understand the research setting from an insider's perspective, (Sackmann, 1991). For this research semi structures interviews, will also be utilised. The advantage with semi structures interviews is that it ensures certain topics are covered making it more comparable and reliable qualitative information, (Patton, 2014). Data saturation refers to the stage when the data collected in the research is now redundant, (Bogdan and Biklen, 2007). This is necessary to ensure enough data has been collected to reflect the perspectives of the research participants, (Kolb, 2012).

To obtain a better understanding of the nature of (OCs) within SMEs in manufacturing industry this study will focus on three main criteria; firstly, to expose the implied components of culture from an insider's perspective. Secondly, to be mindful of structural aspects of the culture for example sub cultures, (Babbie, 2015). Thirdly, to facilitate comparisons to be made among individuals and research settings, (Birkinshaw et al, 2011). The use of these criteria has enabled an issue focused interview style which is founded upon the phenomenological orientation leading to successive comparison, (Birkinshaw et al, 2011). In addition; these focus groups and observations are utilised to provide triangulation of results. Issue focussed investigation allows for the fulfilment of the above criteria. Due to the nature of culture being omnipresent, this makes it difficult for people to often reflect and describe when asked a question about it directly, (Dey, 1999). Therefore, in order to draw this out it often requires a response to stimulus requiring respondents to interpret something, which is naturally done according to their own cultural basis as opposed to that of the researcher, (Sackmann, 1991). Furthermore, and issue focus investigation is particularly suitable because, by presenting them with a stimulus with a specific context, the respondents then tend to access the same library of knowledge already existing in their minds, (Sackmann, 1991). This helps to uncover the framework about a specific issue. This then enables comparisons of the interpretations to uncover individual opinions from cultural beliefs which are common among the group, (Willis et al., 2007). Issue focussed investigation needs to be conducted cleverly to ensure the participants do not realise the issue is under investigation, (Sackmann, 1991). The 
phenomenological orientation has its focus on the insider's perspective and their beliefs and concepts, ideas of the $(\mathrm{OC})$ and life within it. It places emphasis on the insider's view of what is considered important and relevant within that setting, (Goulding, 2005). The researcher will put aside their own assumption so these do not interfere or influence the respondent's answers. The emphasis is to allow the respondents to gradually unravel their own experiences. In order for the researcher to avoid making judgments based on their own beliefs, these should firstly be made clear, (Annells, 1996). The interview procedure in phenomenological orientation is close in style to an in depth or intense interview. This usually consists of a longer introduction and a period of becoming better acquainted. This also gives the researcher the chance to gently introduce the subject of the discussion, (Srubar, 1998). The aspects which are brought up by the respondent are the points which are then delved into with more detail. In doing so, the researcher is better able to explore together with the respondent and identify the cognitive frameworks which come up, (Bryant, 2009). This process of an established dialogue also enables the researcher to check they have understood the respondent's point of view correctly. This can be done by the researcher mentally answering the question in their head before the respondent has a chance to check their own accuracy, (Goulding, 2005). This type of research requires not only flexibility but a rapport to have been well established between the researcher and the respondent because for in depth issues to come to light the interviewee needs to feel comfortable, safe and that a mutual trust exists, (Goulding, 2005). There are some advantages to employing both an issue focused investigation and a phenomenological orientation. The latter is much unstructured and broad however, the issue focus investigation works to narrow the scope giving more structure to the process. Furthermore, the researcher takes their cue from the respondents as to the most important aspects to be further explored, (Sackmann, 1991). The respondents were asking to mention the aspects of Lean they considered most important in their organization (for example). They were also asked to explain why these were the most important. This enables the researcher to cross compare the responses of the individuals increasing reliability. In the phenomenological phase, the researcher ensures all aspects of the factors brought up by the respondents are investigated, (Bryant, 2009). Therefore, this particular approach by Sackmann, (1991) has been selected for this research. In this case the. The questions been asked are issues focussed in accordance with Sackman's (1991) approach: tell me about an example you have seen implementation of Lean work well?; tell me about situation of Lean implementation has not work well?. Therefore, A combination of issues and phenomenological approach proposed by Sackmann, (2006) is being utilized due to its suitability to analyzing (OC). 


\subsection{Research Process}

The research process was divided into three phases as shown in Figure 1. The following subsection will explain each phase.

\section{Phase One}

To begin this phase, the researcher conducted a literature review in order to increase the researcher understanding of the scope of research on the topic of the enablers and inhibitors of 'Lean' in SMEs in much of the literature pointed to OC as being an important factor for why Lean was largely unsuccessful, (Angelis et al., 2011). Therefore, this prompts the researcher to explore more about what has been researched regarding Lean philosophy and OC to identify enablers and inhibitors in this area. The literature review has also helped to broaden the researcher scope of knowledge and theories pertaining to the topic.

In relation to the literature review the researcher has also utilised Scopus, ABI/INFORM Cllection, EBSCO, IEEE, and Website Science, ScienceDirect, Emerald, SAGE,Inderscince and Taylor \& Francis as sources for OC, LI and enablers and inhibitors for SMEs. Having conducted this phase, the researcher commenced on the pilot study. The researcher selected two SMEs in the manufacturing sector in Saudi Arabia where it conducted interviews with managers and employees and from these results the researcher has been able to gather a list of OC enablers and disablers for 'Lean' in SMEs in Saudi Arabia. The researcher then compared and contrasted this list with the information found in the literature review and from the new data uncovered from the pilot study.

The new data which emerged from the pilot study was identified aspects which appeared from the perspectives of the participants not the researcher, (Strauss and Corbin, 1998). The data was analysed with NVIVO software. The pilot study also provides the opportunity to test the questions provided in the seven interviews conducted in the organisation to help to reduce bias and research errors in terms of types of questions provided. An important task is for all researchers to make known their perceptions and thoughts on the issues and topics before research formally begin. This is crucial to mitigating bias in the research process, (Annells, 1996). Then, the research moved to the main study to conduct 29 interviews including with pilot study interview. Then, all the interviews were analysed and compared with literature review. Inter-rate reliability has been utilized in this stage to evaluate the result. When the result reached the saturation level, the researcher moved to the first focus group to refine the aspects were analysed from interviews. The final step in first phase was focus group Tow, the purpose 
for this is to involve the participant to aggregate the aspects into high level themes, and located all the themes within Schein's model.

\section{Phase Two}

The second phase is marked by the beginning of developing an instrument to gauge the current perception of the participants against the ideal position of themes. This involves the participants from focus group Three and literature review to design the assessment. This drove to joint review of the assessment result and their relevance to the organizational culture. In order to gauge the organizational culture more specifically, an assessment tool based on the organizational culture theme description was participatively developed with the participants. Likert scale has been used for this questionnaire; it is to gauge current perception of participants against ideal position. A series of short statements relating to each of the seven themes were developed with the team in focus group Three, to describe an ideal position of the required organizational culture. Statement for each theme indicated the ideal position organizational culture for Lean implementation. The participants assessed their perception of the organizational culture by gauging how close they perceived they were to ideal position of the seven themes, reflecting the ideal position of the organizational culture for manufacturing SMEs. The questionnaire has sent to the participants by email. A total of 71 responses were returned. All the scores were added together and averaged to produce a group perspective of the participants' position against an ideal position for organizational culture.

\section{Phase Three}

In this phase, the researcher will begin to conduct selective of possible intervention from literature review, work field and from focus group Four. The selective of intervention based on themes ideal position that generated from force group Three and from literature review. It is during this phase the framework development begins. Here the researcher will select the proposed interventions and systematically relate this to themes and validate those relationships by expert judgments as the final phase OF the research, (Strauss and Corbin, 1990).

\section{Figure 1 Research Process Phases}

\section{Result}

Semi-structured interview: The researcher conducted twenty-nine semi-structured interviews with all companies, where they currently face barriers to implement Lean (Karim et al., 2011) . The sampling has been selected based on their experiences. The participants ranged in terms of their position in the organizations. Therefore, the sampling method refers more to events and incidents as opposed to 
participants, (Corbin and Strauss, 1990). Having conducted the main study using semi-structured interviews, codes were developed; these can be seen in the Table 2 below.

Table 2 Organizational Culture aspects which influences Lean implementation

Focus group: The participants involved in the focus group discussions included two CEO's, production engineers, mechanical engineers, chief engineers and two workers. The dates and times were pre-arranged based on the availability of the candidates and interviews were conducted in a private office within a hotel.

The researcher conducted four focus groups after concluding twenty-nine semi-structured interviews. The sampling for all focus groups has been selected based on the candidates' experience. All focus groups had the same participants. The participants engaged in a process to review the results from the semi-structured interview in focus group one, with the objective of making suggestions to grouped the aspects to high level theme in focus group two. The purpose for this focus group one is to help refine and further develop the findings of OC aspects from semi-structured interviews. This allowed participants to express their opinions more easily by discussing real examples, thus allowing for a thorough, detailed and intensive data set. The observations were noted by the researcher scrupulously. To conclude, participants reviewed the results of the output from the stage one data collection (interview). Thus, bringing about 39 codes and providing definition for each code (see Table 3). The results of analysis were discussed with participants in focus group two where themes have been developed (see Table 4) the participants starting to group the aspects in seven themes, and provided definition for each category. This drove to joint review of the assessment result and their relevance to the Lean in focus group three, to gauge the Lean culture more specifically. An assessment tool based on the themes description in Table 4 was anticipatively developed with the participants in focus group three. Likert scale has been used for this questionnaire; descriptions of what a Lean culture would "look like" and "feel like" were developed for each of the themes. A series of short statements relating to each of the seven themes were developed with focus group members and literature review to describe an ideal Lean culture position (see Table 5). A total of 71 responses were returned. All the scores were added together and averaged to produce a group perspective of the participants' position against an ideal position for organizational culture in Table 5. The result is shown in Table 6. The result indicates the number of issues that were identified, see Figure 2. It is noticeable that all the results were in the dissatisfaction area. The lowest scoring theme was change management and behaviour patterns, where Quality risk management was the highest theme. What stands out in this figure is the 
organization 'a strategy and vision, change management behaviour patterns and Sustain continuous improvement were close to each other in scoring sheet. In summary, these results show the current state of the position for the firms regarding Lean Implementation from the participant's perspective.

The participants engaged in a process to review the results from focus group 3, with the objective of making suggestions to facilitate Lean culture in focus group four. The assessment results were used as the basis for exploring the issues associated with these scores and possible methods of improving themes. Brainstorming was used to gather the focus group team's ideas related to developing Lean culture. These ideas were discussed and refined in an iterative process to develop possible interventions that would facilitate aspects of Lean culture. The output from the discussion was a list of interventions. These were considered to be feasible for the team members and management, to be realistic in their intent and to be capable of developing Lean culture. In addition, a literature search identified interventions relevant to developing lean culture, the selection of interventions based on enhancing the theme and reaching the ideal position in Table 5. This provided examples of interventions used, how they were implemented and their perceived influence on changing the lean culture. Interventions in the context of this research refer to specific actions that have been or could be applied to a group with the objective of facilitating aspects of lean culture. Evaluation of these interventions permitted a framework for SMEs to be developed. A plan of linked interventions designed (see Table 7) to develop aspects of lean culture forms the output of phase three. The planned interventions for SMEs are should take place together as a series of interlinked interventions. The interventions come from two sources literature review and data gathering. The interventions address the gap between the current situation and the idea position of emerged themes

Table 3 Aspects of Organizational Culture influencing Lean Implementation

Table 4 Themes developed

Table 5 Ideal position for literature review and focus group

Table 6 Organizational Culture assessment scoring result

Figure 2 Result from Organizational Culture assessment scoring sheet

Table 7 Final version of the framework 


\section{Framework development}

The result of the assessment of gauging current perception in Table 6 presents an evidence of areas of inadequacy with respect of lean culture. The interventions from literature review cover a wide spectrum and are more explained than those suggested by the participants. In addition, the suggestion interventions from data gathering were made within the context of this research. An intervention was developed into lean culture framework to facilitate lean implementation. The framework was built on interventions identified from the literature and data gathering. The flaws recognised in the lean culture assessment from gauging current perception furnish guidance for lean culture aspects that must be adjusted. These interventions are monitored by desired effect from literature review and by particular situation of the lean culture to introduce a series of proposed interventions appropriate for nudging the lean culture to be more caring of lean implementation. The planned interventions for SMEs should be acted on together at the same time to develop the climate of lean culture and concentrate on developing confidence to adopt, select and commit to the organisation. This is likely to motivate behaviours that improve lean implementation. These interventions were used as cornerstone for developing SMEs manufacturing-specific interventions invented to create the settings for a lean culture... The framework comprises the following eight interventions:

\section{Knowledge management and share system}

Central knowledge-share management matters in SMEs is the existing of knowledge loss through key employees departing the companies (Wong and Radcliffe, 2000; Wickert and Herschel, 2001; Finn and Phillips, 2002). SMEs are exposed to this phenomenon, since individuals are continually looking for better careers and job prospects and higher wages in larger organisations. Without doubt, when employees leave a firm, they will take with them all the experience and knowledge that is firmed in their mind (Yew Wong, 2005). Retaining employees in the firm is highly entrusted on effective people-management strategies. Actually, people management perform a much broader role and it lies at the heart of knowledge-share management (Yew Wong, 2005). From the above review, it has not been frankly directed as a crucial aspect for Knowledge-share management. Face-to-face communication guide to transferring of knowledge, information sharing, which improve equality in the team and also prepare a primary move for continuous improvement by having daily minor meetings, etc. (Holmdahl, 2010). 
This stage covers identifying the types of knowledge that will generate the most value for the organisation and then producing mechanisms for growing that stock of knowledge. It starts with investigation of the organisation's competitive strategy - how it seeks to create customer value to achieve profitable results. Once the knowledge required for competitive strategy is identified, organisations need to devise mechanisms for acquiring or creating that knowledge, and then it will be easy to create master plan by using this technology (Huse, 1980; Al-najem, 2014). Databases, computer networks and electronic bulletin boards and discussion groups originate a forum and an electronic society of practice that improves contact between the person looking for knowledge and those who may have reach to the knowledge. For instance, this may be achieved by posting a question in form of 'does anybody know', or a 'looking for help' to the discussion group. These tools may extent the available knowledge both vertically and horizontally in organisations (Alavi and Leidner, 2001; Anand et al., 2009; Achanga et al., 2012; Albliwi et al., 2014b). They also speed access to knowledge and enhance the communication (E. H. Schein, 1990b; Paiva, Roth and Fensterseifer, 2008; Albliwi et al., 2014b), and this was supported by one of the participants No.3:

using the last technology or database system is the right stage for setting up measurement goal and metric to enhance the strategy of the organisation.

It is not new that one of the most common applications on intranets are corporation directories. Such directories do not include the knowledge themselves but enhance individuals to speedily locate the individual who has the knowledge that might help them resolve a present problem. For instance, at Hewlett-Packard, the main content of one system is a set of expert profiles covering a directory of the skills, backgrounds, and expertise of individuals who have knowledge on several topics (Davenport 1997a). These directories allow individuals too much more rapidly locate the knowledge needed for problem answering. Often such metadata (knowledge about where the knowledge resides) shows to be as significant as the original knowledge itself (Andreu and Ciborra, 1997).

\section{Managing family influences}

This intervention can be achieved through implementing a process where family influences are excluded from decision making related to Lean by conducting a review board to prevent family members from interfering with the whole organisation process, where the board could be from member of the company such as manager or worker, as the participants from interviews and focus group agreed that managing the family influence will create a climate of lean culture. In 
addition, family-maintained businesses have a shortage of abilities to implement lean expires, which makes them delay behind non-family-maintained businesses (Astrachan and Kolenko, 1994; Al-najem, 2014). Graves and Thomas (2006) also found that the non-family-maintained organisation have well managerial skills compared to family-maintained organisation. This relationship was identified when a participant No. 17 said:

The managers who own the business never trust us when we do our job... just we take an order from him, all the time.

Another participant No. 9 added:

There is a need to a system where the manager (the owner) should manged and controlled through a system.

This intervention would provide the trust among the employees and the freedom to increase their skills by select the right decision-making (Ellington, Jones and Deane, 1996; Levinson, 2011; Achanga et al., 2012; Gupta, Acharya and Patwardhan, 2013)

\section{Health and safety climate and policy}

In this intervention, 'policy' indicates the general goals, approach and objectives - vision - of firm and the standards and principles upon which it bases its action, these form the foundation for managing health and safety which establish the written statement of policy required, policy is used in relative to health and safety (Ally, 2008). The health and safety policy should represent the responsibility of employers to deliver a healthy and safe working environment. Everybody should be made responsible for a duty unless they meet appropriate competence standards. This will give a name or position to the health and safety team (Cooper, 2000; Safe Work Australia, 2013; Camuffo, De Stefano and Paolino, 2017), bring policy information to the notice of every single worker, supervisor and manager; provide, where needed, for measures to adjust with emergencies and accidents, as well as adequate first-aid arrangements; afford equipment without cost to the worker and adequate personal protective clothing, when hazards cannot be controlled; collaborate with other employers in enhancing occupational health and safety; as well as weekly toolbox discussions with supervisor which may consist of, for instance, a reminder of significant health and safety procedures or trainings from a current accident and managing meetings of the central health and safety board (Maestas and Parrish, no date; Dale and Cooper, 1992; Safety and Executive, 2008; Wong, Wong and Ali, 2009a; Camuffo, De Stefano and Paolino, 2017). 
This intervention seeks to provide practical advice and recommendations on progressing an occupational health and safety climate for the firm. The words 'safety and health' are used throughout the document for conciseness and to contain the health and safety. This intervention is not planned to be a specification or to be used for certification aims. This intervention will enhance (Vincent, 1997; Hsa, 2006; Alli, 2008; AL-Najem et al., 2013; Longoni et al., 2013; Safe Work Australia, 2013), explains the principles and management exercises that provide the foundation for dynamic occupational health and safety management; sets out the questions that need to be addressed and aids as a tool to progress improvement programmes, self-audits or self-assessments.

\section{Feedback system}

Shah and Ward (2007) highlighted providing a feedback system on delivery and the quality of products, as this will lead to improve the association among the employee and avoid flaws in the future. In addition, Yusof and Aspinwall (2000) added that feedback systems are one of the most important CSF for implementing lean within SMEs. Forza (1996) mentioned that in order to attain successful lean implementation the firm entails certain features, for example: Employee proposals (feedback and realisation) that are taken earnestly; Feedback about quality performance to supervisors concerning features of quality performance for example waste reduction; Regular feedback to workers on the present processes, defect rates, machine breakdowns, etc.; and The use of physical meeting for example face to face. There is a heavy dependence on quality feedback altogether supervisors and workers (Forza, 1996). According to Womack and Jones (2003, p. 15), lean thinking 'provides a way to do more and more with less and less human effort, less equipment, less time, and less space [...], provide[s] customers with exactly what they want, [and also offers] a way to make work more satisfying by providing immediate feedback on efforts to convert muda [waste] into value'.

\section{Recruitment and selection process to select appropriate persons}

This intervention is a procedure of seeking for and having potential job applicants from a target pool, campus, or specific area, allowing employers to select the most appropriate candidates to fill the job requirements. In actual fact, there is no best method or commonly accepted process on how to recruit and select candidates because different employers have variety recruitment and selection approaches depending on their needs, operations and size (Leat and El-Kot, 2007; Olsen, 2015; Su and Yang, 2015). Selection actions are considered important to recognising people who hold capabilities that allow them to make an active involvement ( $\mathrm{Su}$ and Yang, 2015). However, the recruitment challenge for SMEs manufacturing organisation is not only 
to run vacancies under swinging business demands, but to recruit high-quality talent that is sought after by plentiful manufacturing organisation (Macduffie, 1995; Nordin et al., 2012; AL-Najem et al., 2013; Zhou, 2016). The role of selection is considered essential to the exercise of strategic human resource management as employee capability is seen in the achievement of employee contributions to the understanding of strategic goals. Selection actions are considered essential to recognising people who own capabilities that enable them to make real contributions (Radeka, 2009; Testani and Ramakrishnan, 2012; AL-Najem et al., 2013; Dombrowski and Mielke, 2014b; Nolan and Garavan, 2015; Su and Yang, 2015). Knowing people's abilities is another significant exercise that supports to prevent wasted talent. By identifying people's abilities, top management and leaders can simply allocate the exact people to the correct tasks (Achanga et al., 2006; Panizzolo et al., 2012; Dora et al., 2013b)

\section{Top management and leadership commitment}

Top management and leadership is the most vital aspect used for lean implementation, as identified by several scholars (e.g. Chin and Pun, 2002; Angelis et al., 2011; Bakås et al., 2011; Zu et al., 2010; Mefford, 2009; Kumar et al., 2009; Achanga et al., 2006; Panizzolo, 1998; Meredith et al., 1991; Snee, 2010). Lean implementation cannot be established and sustained without top management and leadership commitment. Central aspects such as commitment, knowing people's capabilities, visible management (Gemba), knowing talent people, committing to providing training, respond to feedbacks, motivation and investment in consultants, rewarding system and expertise can support the firm to advance, and avoid inefficiencies such as 'wasted talent' (Achanga et al., 2006; Kumar, Antony and Douglas, 2009; Al-Najem, Dhakal and Bennett, 2012; Panizzolo et al., 2012; AL-Najem et al., 2013; Dora et al., 2013b; Albliwi et al., 2014a, 2017). Commitment from top management is highly essential for lean implementation. This can take several methods, for instance, investing in expertise, consultants and training (AL-Najem et al., 2013).

\section{External input}

This intervention will enhance the training and increasing the knowledge by investments in consultancy, hiring specialists to enhance the work and benchmarking and this involves commitment from top management and leadership who be certain of in enhance the process, this will lead to improve continuous improvement (Inman and Mehra, 1990; Boughton and Arokiam, 2000; Achanga et al., 2006; Sim and Rogers, 2008b; Boyle and Scherrer-Rathje, 2009; Puvanasvaran et al., 2009; Bhasin, 2011; Kundu and Manohar, 2012; Nordin et al., 2012; Dombrowski and Mielke, 2014b). In addition, participants from semi-structured interview and 
focus group added that to visit other firms to collect best practises should be required to increase knowledge. Involving external expertise can identify the gap that may exist within the organisation between the change effort and the firms members (Al-Najem, Dhakal and Bennett, 2012; Nordin et al., 2012; Panizzolo et al., 2012; Panizzolo, Bernardel and Biazzo, 2014; Asnan, Nordin and Othman, 2015).

\section{Training and education to increase knowledge of lean practices}

This intervention focusses on the individual training needs for employees related to the work they are doing in their current positions. Development needs may also be assessed to identify skills or abilities that the employee will have to possess to grow into future positions. Companies may also assess employee needs when deciding whom to select for training. Methods to gather information about employee needs include surveys, face-to-face interviews, formal tests, job records, and simple observation of employee performance (Beer and Walton, 1987; Yew Wong, 2005; Ismail Salaheldin, 2009; Arshida, 2012; Deros, 2014; Laureani and Antony, 2016a). In addition, assessments of organisational training and development needs will attempt to target any deficiencies and build on strengths while shaping future needs at a strategic level; identifying the knowledge, skills, and abilities needed for meeting future needs will drive training and development plans. An HR audit may be used to take a macro look of the needs of the entire workforce. Other measures such as turnover and retention analysis and studies of employee absenteeism rates help employers identify where HR interventions may be appropriate (Wright and McMahan, 1992; Macduffie, 1995; Bhasin and Burcher, 2006; Leat and El-Kot, 2007; Ali, 2010; Su and Yang, 2015; Laureani and Antony, 2016b). The motives for implementing lean must be well enjoyed and agreeable and firms must supply regular training plans to all employee involving in implementation of lean (Turesky and Connell, 2010; Worley and Doolen, 2006). To investing in training may support in creating employee with multi-tasking abilities that are eligible to identify process bottlenecks and associate to waste reduction (Panizzolo, et al. 2012). Table 7 summarises the proposed interventions for SMEs. The programs of training are typically given by hired consultants or in-house lean champions and merge both classroom training with shop-floor practices (L. Bamber and Dale, 2000; Dahlgaard and Mi Dahlgaard-Park, 2006; Albliwi et al., 2014b; Panizzolo, Bernardel and Biazzo, 2014). 


\section{Rigour in the research}

Between qualitative and quantitative research many differences with respect with their evaluation as part of the research (Guba and Lincoln, 1989). Quantitative research is evaluated on the basis of reliability and validity (Lietz and Zayas, 2010, p. 190). Mason, (1996) suggests that reliability; validity and generalisability vary in terms of measurement of the quality, rigour and its potential to be applied to broader situations. Validity can be defined as, "whether you are observing, identifying, or measuring what you say you are," (Mason, 1996, pg. 24). In contrast LeCompte and Goetz, (1982) refer to reliability and validity by distinguishing between 'external reliability' and 'internal reliability'. External reliability refers to the extent to which a study is able to be replicated. Some recommended strategies for duplicating qualitative research is to take on a comparable role taken on by the original researcher, (Bryman and Bell, 2015) Internal reliability refers to if there are numerous observers or just one, and the agreement among the observers of what they are exposed to. Internal validity refers to how well the observations made by the researcher matches the theories they comprise, (Bryman and Bell, 2015).

According to LeCompte and Goetz (1982) internal validity is a key strength available to qualitative research especially where the researcher spends a high period of duration within the research environment thus helping to ensure the strength of compatibility between concepts developed and observations. External validity refers to the extent to which the results are able to be generalised over various social situations, (Bryman and Bell, 2015). According to LeCompte and Goetz (1982) this is the most problematic area for qualitative research as it tends to utilise smaller sample populations and for case study purposes. However, (Guba and Lincoln, 1994). Propose a further method for evaluating qualitative research which is based upon four criteria;

\footnotetext{
i. Credibility, which refers to internal validity

ii. Transferability, referring to external validity

iii. Dependability, paralleling reliability

iv. Confirmability which refers to objectivity.
}

Their reasoning for challenging the notion of merely reliability and validity is due to its assumption that an absolute count of a social situation is possible, (Bryman and Bell, 2015). Guba and Lincoln (1994) however, hold that more than one absolute truth is possible in multiple situations. Therefore, this emphasis on multiple accounts for social realities is particularly relevant when considering the criteria of credibility in qualitative research. 
Furthermore, if a number of possible accounts of an aspect of a social situation ae possible, it is the credibility of that account which will ultimately determine how acceptable it is. This is essentially where respondent validation becomes an important factor. Triangulation is also another technique which is recommended to deal with this issue, (Bryman and Bell, 2015).

Since, qualitative research is more subjective reliability and validity is in compatible with it. Consequently, validity and reliability are not being not suitable measurement in qualitative research. The reason behind this is because the measurement change position to the positivist approach instead of the approach of interpreted (Angen, 2000, p. 379; Liamputtong and Ezzy, 2009, p. 21). Lincoln and Guba (1985; 1989) have developed tour criteria as mentioned above, these guiding principles used to evaluate qualitative research and considered as should not to be rules for using validity and reality inside positivist research (CARPENTER and SUTO, 2008, p. 150; Lietz and Zayas, 2010). These criteria where applied to this research is listed in the Table 8 below:

Table 8 Criteria for ensuring rigour in qualitative research (Liamputtong, 2009)

In this research, the inter-rate reliability took place in early stage of the analysis process. The procedure is that having two or more judges independently to determine the significances, degree and sample stability of their agreement(Rashid, 2010). Gwet (2002) provide that evaluation the extent degree of the agreement between two or more ratters is common use in social, medical sciences and behavioural. He gave an example of a reliability experiment where two rater (A and B) should classify $\mathrm{N}$ subjects into one or two potential response i.e. (1 or 2), (Yes or No) etc. the categories are suggested as disjoint (no overlap) (Rashid, 2010). The researcher has used the inter-rate reliability to validate the aspects. Inter-rater reliability of 0.73 Cohen Kappa and 96\% Percentage of Agreement were obtained during analysis. The result shows in Table 9.

Table 9 Inter-rate reliability result

\section{Discussion}

The link among organization culture as well as Lean manufacturing implementation is highly critical and sensitive, Organizational culture is the most common and factor as the authors agreed to be considered. Firms should take these challenge matters into their consideration when adopting and apply Lean manufacturing. Organizational cultural contribute for Lean 
cooperation is recommended to apply and the implementation basics of the Lean manufacturing (Pérez-porras et al., 2014; Chen and Meng, 2010a). In addition, the research on lean implementation is growing. Many researchers from different backgrounds have started to investigate, analyse, describe and explore the concept of lean. In this research, the exploring was necessary in order to identify the lean implementation CSFs, inhibitors and enablers in terms of organizational culture aspects to develop a framework to facilitate lean implementation within SMEs in manufacturing sector. Despite the existence of literature in lean, it was observed a lack of efforts conducted to determine how the existing service offering process can be enhanced and improved using organizational culture aspects. In addition, the researcher discovered that there is no such a research focusing on lean implementation within in SMEs manufacturing sector in Saudi Arabia. The research into this topic is booming, and companies are striving to adopt lean practices in their process. Furthermore, the implementation of lean can be considered difficult and challenging. So, few companies succeed in their lean journey. Despite the vast research carried out on lean manufacturing, few attempts were made to precisely define how lean practices can be implemented in SMEs. Little effort has been made on developing a framework for implementing lean, as well as, little effort has been made on identifying the enablers and challenges of implementing lean in SMEs. Most lean SMEs research has been conducted in the western context with an emphasis on Lean implementation. It is advocated that this research will help develop the state of knowledge in the subject area and support the converging of divergent views towards a more precise, standardized understanding and approach in researching Lean in SMEs.

Many factors affecting the lean implementation in SMEs. The data collected from semistructured interviews with 29 participants in SMEs revealed factors including many decision makers as well as a lack quality worker in term recruitment, motivation and reward system, education and skills, technology, knowledge of LI, Teamwork \& leadership attitude and Health $\&$ safety. An influence of family owners, resistance to change and training, were the dominant factors highlighted in the interviews, since these factors affect the firms' ability to create a quality lean culture due to the constraints they place on teamwork and effective communication. Moreover, it was found that the firms do not follow a clear strategy in terms of involving employees in improving processes, nor in promoting Continuous improvement. Most of the firms do not have good practices in place, and too many issues have been ignored, such as labelling items, equipment and floor, providing designated areas for tools and equipment, ensuring the condition of tools and equipment is good (i.e. caring about their 
equipment), using VM methods (such as charts, instructions, schedules, etc.), providing a safe working environment (ventilation, health and safety clothes etc.), using a process layout (with good flow, ow WIP, etc.), providing storage areas and workers' uniforms, keeping the workplace, storage areas, etc., clean and tidy, implementing suggestions systems, providing workers' break rooms, and keeping records of important issues, such as cycle time, lead time, etc. The structured observations led to a better understanding of the outcomes from the semistructured interviews. Furthermore, data gathering gave an even clearer picture with respect to what is going on within SMEs it has been found that shop-floor workers are generally ignored by the top management; in addition, no real contribution is forthcoming from them, for reasons such as a lack of quality in terms of the workers themselves, trust, loyalty and the fact that top management are not trying get workers involved. Furthermore, data gathering show that top management are not involving people as they should, and this was manifest in the fact that many workers within the firms do not agree with or believe LI, but have been forced to accept it by top management. This was also shown in the semi-structured interviews with the 29 participants. Moreover, a shortage of training and recognition was highlighted in this study, and it was found that SMEs are not adopting scientific methods to solve problems and improve processes. According to Mersha (1997), LI requires skilled people with an ability to work as a group and solve problems. This finding is consistent with Antony et al. (2008), who found that SMEs do not provide enough training, due to financial constraints. Additionally, understanding and awareness of the benefits and principles of lean have been found to be very low, and knowledge of lean implementation is missing in SMEs. This finding is consistent with previous literature (Youssef and Zairi, 1995; Al- Khalifa and Aspinwall, 2000; Garza-Reyes et al., 2011), which suggests that Saudi Arabia and nearby regions are far from maturity in terms of LI.

It is worth mentioning that the focus group was conducted after conducting semi-structure interview, During the focus group, the process of themes becomes more structures by aggregate the aspects that effecting LI within SMEs, in order to validate relationships within the data and the agenda becomes more deliberate in order integrate the findings within the themes. A series of short statements relating to each of the seven themes (Communication \& interaction in the organisation; Organisation's Strategy and vision; Organisation's Infrastructure of the workshop; Quality risk management; Human Resources Change management and behaviour patterns and Sustain continuous improvement) were developed with the team in focus group. In addition, to gauge current perception of participants, an ideal position has been developed 
for each theme from literature review and data gathering. A series of short statements relating to each of the seven themes were developed with the team in focus group and from literature to describe an ideal position of the required organizational culture to create a desired lean culture of ideal position. From the ideal position for each theme a questionnaire has been developed and sent for gauging current perception of participants, the result present that all the themes located in a disagree level. The questionnaire outcome showed negative sign for all themes. This variable highlights many negative aspects within SMEs that can be perceived from the low scores and are indicative that these firms are not ready for LI or struggling to deal with LI.

As has been discussed in previous, the framework that has been outlined in this study is based on eight interventions developed from literature review and data gathering to facilitate lean implementation within SMEs to enhance the eight themes were developed during the research (see Table 7). The results from gauging current perception of participant's shows that change management and behaviour patterns and sustain continuous improvement are perceived as being low. In addition, the participants also feel that management and leadership support and commitment for activities is low. Moreover, the influence of the owners of the firms is extremely affecting the entire process of lean implementation. In evaluating interventions to develop lean culture, the interventions pooled from the literature review and data gathering indicates a need to provide strong commitment, support from leadership and managing the family influence to facilitate lean culture. This provides a legitimacy for what could be considered as counterproductive practices for top management and leadership commitment and managing family influences in the business context In SMEs, the sufficient power to influence the process of lean implementation is the family owners, which often effecting the entire process and lacked support (e.g. decision making, training, responsibilities and behaviour) to apply lean. The findings also disagree with several authors (Welsh and Raven, 2006; Chua et al., 1999; Davis, 1983) who have claimed that family-owned businesses are likely to have better relations with customers and be better able to manage their resources; neither of these was shown in this study. Also, the findings contradict those of Reid and Adams (2001), who suggested that business practices with respect to human resource management (HRM) differs between the two types of firms, with family-owned businesses having distinctive HRM practices compared to non-family- owned businesses - although the authors did not say which business type has better practices. This result is agreed with those of many researchers (e.g., Ellington et al.,1996; Levinson, 1987; Ward, 1988; Hofer and Charan, 1984), who found 
differences in the implementations of lean practices by the two types of family- vs. non-familyowned firms, and suggested that non-family-owned organisations have a better chance of adopting lean practices. Ellington et al. (1996) found that family-owned firms are adopting fewer quality and management practices, because they are more short-term oriented. Further, Ellington et al. (1996) explained that family-owned firms are more centralised in their decision making, as the top managers are involved in every decision; therefore, they cannot adopt a holistic approach towards management capabilities. Further, the findings agree with Astrachan and Kolenko (1994), who claimed that family-owned businesses have a shortage of capabilities to implement HRM practices, which makes them lag non-family-owned businesses. Graves and Thomas (2006)also found that the non-family-owned firms have better managerial capabilities compared to family-owned firms; this was not the case in the present research study, as both types of firms in the KSA context were found to be in a similar position with regard to the use of lean practices.

Top management ownership and involvement is critical to the success of the proposed interventions. This must be visibly demonstrated to the participants throughout the intervention process. Provision of adequate resources, managing talent, motivate employee and demonstration of an interest in progress of the interventions and resulting successes and failures will support this. Top management must take care not to assume control of the interventions. The responsibility for implementing interventions 1 to 8 lies with employee. Top management must facilitate, encourage, take an interest, but at all stages it must allow the employee to retain control and ownership of these interventions. This sets the vision for lean implementation, the perception that experimentation, learning and discovery are valued and are part of the "way things are done now" in the employee. Japanese managers at the top of the organization support enthusiastically with all needed resources and involve themselves personally in the implementation process. . On the other hand American managers often adopt piecemeal approaches and partly commitment of resources for training and process change(Inman and Mehra, 1990; Maxwell et al., 1998; Koeningsaecker, 2005; Kovacheva, 2010; Moosa and Sajid, 2010). However, for firms that are willing to challenge their views and the role of management is on the required level, another barrier is rising. Learning by doing is required in order to receive guidance and enough knowledge to perform the process improvement tasks and to accomplish process improvement goals and vision. Firms that successfully adopted lean experienced most difficulties in the inability of management to change their philosophy. In pursuit of high performance, the real challenge is to integrate the principles of the system- Lean 
which are new for the organization into coherent sequence depending on the specific interorganizational factors.

As has been emphasised by the vast majority of prior research, top management and leadership is the most crucial factor for LI. The role of top management and leadership is manifested in many forms, such as providing clear vision, allocating resources and funding, and providing strategic leadership (Tsang and Antony, 2001). To ensure the success of LS implementation, it is essential for top management to create a quality culture by empowering other employees (Zhang et al., 2000). This factor has been emphasised in various articles (e.g. Chin and Pun, 2002; Angelis et al., 2011; Bakås et al., 2011; Zu et al., 2010; Mefford, 2009; Kumar et al., 2009; Achanga et al., 2006; Panizzolo, 1998; Meredith et al., 1991; Snee, 2010). Furthermore, it was found that the SMEs are lacking in many internal respects, and this has led to a lack of quality culture. These issues include (Lack of knowledge about LI in KSA firms; Lack of knowledge about the key issues that are considered important for LS in terms of respect for people, such as rewards, involvement, motivation, empowerment, etc; No means by which to solve technical issues, as there are no skilled workers, training programmes, or scientific methods in place to solve problems and improve processes; Poor communication between toplevel and shop-floor people; No use of technology by which to communicate between departments and Lack of top-management support and leadership). These factors are contributing towards the lack of readiness for lean within the SMEs in terms of organizational culture. The findings of this study support those of a number of other researchers, such as Graza-Reyes et al. (2011), who claimed that KSA is still not mature enough to understand LI. The low use of lean system identified within SMEs also supports the claims made by Jaeger et al. (2013), who found that lean system is not taken seriously in the GCC region, and are not really used. The findings regarding the lack of leadership focus on customers, and scientific methods for measurement and analysis, are also consistent with Jaeger et al. (2013).

Further, the findings on the lack of CI, empowerment and top-management support are also in line with the findings of Graza-Reyes et al. (2011). They also agree with those of AL-Nofal et al. (2004), who similarly found that there is no involvement and commitment at the shop-floor level, as well as a lack of commitment towards QI from the top management, a lack of quality culture, and no close relationships with customers and suppliers. Further, it was found that the SMEs are lacking top-management commitment and leadership quality, and this is consistent with Ghobadian and Gallear (1997), who found that SMEs owners and top management are 
unaware of key managerial aspects that are essential for initiating QI. This finding is consistent with Yusof and Aspinwall (1999), who identified some of the factors that affect Qatari SMEs with respect to the implementation of QI. Among these factors are: human and technical aspects, lack of resources, and shortages of finance.

In addition, the lack of training found in SMEs is consistent with Antony et al.'s results (2008); they found that SMEs do not provide much training due to financial constraints. Hill and Stewart (2000) also suggested that SMEs offer little training and are reluctant to spend on this area; any training systems that are in place in SMEs are unplanned, reactive, short-term oriented and informal. This supports the present study's results in relation to SMEs, especially from the interviews with the 29 participants, who claimed that they do not have enough money to spend on training and are relying on their firm's initiatives, which do not always fit their firms' needs. Further, when the findings of this study are compared to those of other researchers in the developing country world, similarities can be noted; for instance, in the KSA there is a lack of top-management commitment and support, training and education, supplier quality, worker empowerment and involvement, and customer relations. Kuwait shares these problems with Palestine (Baidoun, 2004), the UAE (Badri et al., 1995), Saudi Arabia (Al-Omaim, 2002) and Qatar (Al-Khalifa and Aspinwall, 2000)

The implementation of lean dose need to be continually revised and reviewed during the lean implementation process. Linked to this, SME owners/managers are suggested to actively seek funding opportunities and support from externals, such as visiting other firms, government agencies and consultants in their Lean journey. The successful of Lean hinges on the recognition of what the employee's needs "employee voice". The outset of any Lean trip therefore, an understanding of the "voice of employee" should be obtained. This will ensure that SMEs can orientate their Lean progress around a precise understanding of employee value and this will need to be continually revisited as values can be highly dynamic. In addition, SMEs are often flatter organizations in terms of their structure and invariably are organized around more informal working relationships. These characteristics enable more direct and quicker communications between managers and employees. It is more likely that the concept of Lean will be more efficiently diffused across the SME so total employee engagement is to be achieved. In addition to communications and training employees is another important task in the Lean implementation program. However, SMEs are often criticized as lacking in support of knowledge development, which is a requirement for Lean initiatives. In this sense, SME 
owners/managers may need to consider the involvement of external professionals in their Lean journey.

Before embarking on Lean implementation, it is important for the SME to be confident in the quality, health and safety of its processes and its components and finished products. Lean, removes buffers of time and inventory and requires a right first-time operation. If quality, health and safety levels are unreliable, there is a danger that the implementation of Lean will result in serious breakdowns and failures for customers. An audit of quality will give a full appraisal of whether the SME is ready for Lean or not in terms of the workshop infrastructure. By given the supportive of financial capabilities and human resources for training, motivate, apply feedback system and implement knowledge management system, possessed by SMEs, can be applied at the outset of their Lean journey will enhance for lean implementation process.

Firm size does not seem to have an impact on the lean culture used; both types of firms were found to have a similar level of quality and management practices, and there were no significant differences in terms of size, which is in accordance with Mallur et al. (2011). However, this result contradicts Mady's (2009) findings, which suggested that there are significant differences between small and medium-sized in Middle East industries, and that medium-sized firms use lean implementation more effectively. Further, Mady (2009) demonstrated significant differences in customer focus between the two firm sizes, especially in terms of dealing with process quality. He found that medium-sized firms make better use of benchmarking, process improvement and data-driven decisions.

The results show that there are no significant differences between the six different sectors (Steel manufacturing; Electric manufacturing; Oil manufacturing; Paper manufacturing; Packaging manufacturing and Construction manufacturing) in terms of the use of lean implementation practices, since the perception score for the six sectors was found to be almost identical, and none of them have succeed towards LI. This result agrees with Mady (2008), who found that there are no differences among the different types of sectors in KSA and the region in terms of their perception of competitiveness priorities such as flexibility, on-time delivery, cost reduction, innovativeness and quality improvement. The reason for this could be attributed to the lack of competitiveness in the market, and the fact that most types of industries are supplying to the local market; however, these results differ from those of other authors (Reed et al., 1996; Corbett and Rastrick, 2000; Curkovic et al. 2000), who verified that different sectors have different uses of quality and management practices. Further, this result is not in 
agreement with Mady (2009), who found that there is a difference in the quality and management practices used by different sectors in KSA and the region, Mady (2009) focused on two sectors only, including food, while this study considered six sectors, of which the food sector was not one. This finding also disagrees with those of Ab-Rahman et al. (2011), who identified different quality and management practices within Libyan manufacturing industries. Similarly, this study does not support the findings of Paksoy et al. (2011), who found that there is a difference in terms of the perception of TQM within four sectors (iron-steel, automobile, textile, and plastic); they highlighted that the iron-steel sector is making the strongest TQM efforts, while the textile sector was found to be the worst sector in this regard.

Furthermore, this study did not support the findings of Taj, (2008), who found that there is a difference in terms of lean practice usage within different sectors in China (electronics, telecommunication, wireless, computer, food/beverage, garment, pharmaceutical, chemical, petroleum, printing, $\mathrm{A} / \mathrm{C}$ and heating); Shahram found that the petroleum industry was ahead of all other industries, followed by computer, telecommunication/wireless, electronics, garment, food and beverages, pharmaceutical, printing, and $\mathrm{A} / \mathrm{C}$ and heating industries, respectively. As was explained in Chapter 4, sector has not been emphasised as a factor that affects LI, as many authors have suggested that LI can apply to many different types of industry (Womack et al., 1990; Soriano-Meier and Forrester, 2002). Further, this study is the first to deal with LI in the KSA context, so it is necessary to build a foundation from which to obtain a better understanding of KSA firms. Thus, the findings on sectors cannot be compared to any great extent with those of previous studies.

It was found that the developing country necessarily needs a framework to facilitate lean implementation process within SMEs (Safety and Executive, 2008; Karim et al., 2011; AlNajem, Dhakal and Bennett, 2012; AL-Najem et al., 2013; Al-najem, 2014; Albliwi et al., 2014, 2017). Furthermore, many researchers (e.g., Nordin et al., 2012a; Radnor et al., 2006) have pointed out the importance of a framework before implementing LI. This study has addressed this gap by developing a framework that facilitate the lean implementation for organisations as it contains most of the lean requirements interventions that represent the foundation of LI, as extracted from the literature review and data gathering. The framework provided here is simple and easy to use, and will allow managers to understand their current practices to see whether they are supportive of LI, or if things need to be addressed before implementation. This will make it possible for managers to know whether they have the required resources for LI, and to learn whether they are able to afford these interventions. If 
managers are not willing to implement these they will have a minimal chance of success in LI, as LI requires all interventions mentioned. The framework is not limited to use in KSA, as it was derived from different studies around the world, and most of the items are applicable to all types of manufacturing industries. Further, as most Arab countries - and, more precisely, those in the GCC region - share similar cultures and values, the results can be generalised to them, bearing in mind that LI requires certain types of cultures, in both an organisational and a national sense(Al-Najem, Dhakal and Bennett, 2012; Al-najem, 2014).

The findings in this study show that one of the aspects that has prevented Saudi Arabia SMEs from adopting LI are family owners influences on the decision making and top management commitment, alongside other characteristics such as the country's wealth and high dependence on expatriates; all these issues are applicable to most of the GCC countries, so it is believed that the findings can be applied to other Arab countries, especially GCC countries. Gherbal et al. (2012) found that Libyan industries are adopting TQM for prestige purposes, not for improvement. Further, Jaber (2010) found that favouritism is affecting Libyan readiness towards TQM. Additionally, Bardot (2013) explained that most of the GCC countries are eager to improve and are striving to reach the right solutions, but also do not understand these solutions and do not know how or where to start. The framework could be one of the solutions to boost the SMEs manufacturing sectors, so the findings of this study can serve as guidance for the GCC countries, especially for small, local organisations and government entities who do not have partnerships with Western companies. Bardot (2013) suggested, there is a need for intensive education so that GCC countries will accept modern practices. Furthermore, the framework can be applied in any manufacturing industries regardless of location, as it contains key foundational aspects of LI; thus, any firms that want to adopt lean system can use the framework to facilitate lean implementation if they have the same social setting as in this study.

The Saudi Arabia government is trying to reduce its reliance on oil and gas, and supporting SMEs manufacturing sector by applying 2030 vision as a road map for the country, this could be key to achieving this vision. Thus, in order to ensure the success of LI and to enhance the role of SMEs, the government needs to pay attention to this sector by encouraging firms to adopt the framework, and developing awareness campaigns that highlight the importance of the framework and explain the requirements for the implementation process. This can be done by providing SMEs with appropriate training and workshops. The findings of this study show the weaknesses of SMEs in KSA and the requirements for framework to facilitate LI, which can be used by the government to formulate some action points in this direction. Potential lean 
manufacturing users can make informed decisions on the overall economic viability of its adoption at an early stage. Companies may also strategize the framework adoption based on factors such as cost, readiness, benefit analysis and risk assessment. Expert's inference reiterated that the framework can be better used in the facilitation of lean culture, to help implement lean; this would be a catalyst in a given company.

\subsection{Making the change}

In the literature and data gathering, there is a clear requirement to have strong top management commitment and managing the influence of the family owners. The participants expressed concern about the influence of the family owners in the business process and the top management support for lean culture during the interview stages. In addition, the scores on the assessments in the stage two (see Figure 25) indicate poor Change management and behaviour patterns, Sustain continuous improvement and Organisation's Strategy and vision. From the data gathering, it is salient that participants have provided a degree of resistance to do things differently by top managers, leadership and family owners of the business. Thus, it is not surprising then that from data gathering that the people would want to be guided by management, would want to take steps that improve on what they have currently got and would be wary of moving away from the pattern of behaviour that they know, and are comfortable with, to undertake a series of interventions that require a different way of behaving. The suggested interventions for facilitating aspects of LI supporting culture in SMEs will depend heavily on family business owners and on top management support and input. A key part of this support is the creation of a strategy and a vision for the companies (Malik et al., 2007; Nordin et al., 2012). This acts as a model of the desired position for development at the end of the transformation. Based on the literature review, data gathering and studies of several organizations that underwent change programmes, there are many different interventions suggested from literature and data gathering (Lucey, Bateman and Hines, 2004; Achanga et al., 2006b; Yogesh, M., Chandramohan, G. and Arraka, 2012; AL-Najem et al., 2013; Shokri, Waring and Nabhani, 2016; Albliwi et al., 2017). These have common themes that indicate which aspects of lean culture they would influence. The creation of the desired culture is more likely to be achieved by considering an appropriate group of interventions acting to modify the behaviour of the team members, and then reinforcing that behaviour such that it becomes embedded in the underlying values of the group (Schein, 1991).

The success of a small business or an SME can be linked to how well they manage their knowledge (Dollinger, 1984; Brush, 1992; Brush and Vanderwerf, 1992). Knowledge to 
represent know-how, expertise, tradecrafts, skills, ideas, intuitions, and insights. Knowledge management has been shown to a powerful ingredient in the success of organizations in strategic level (see for example Nonaka and Takeuchi, 1996; Davenport and Prusak, 1998; Desouza and Awazu, 2006) Organizations who are successful in leveraging knowledge, normally witness increased to improve their communication, strategy and vision, efficiencies in operations, higher rates of successful innovations, increased levels of customer service, and an ability to have foresight on trends and patterns emerging in the marketplace. Besides the traditional reasons for managing knowledge, SMEs must pay close attention to knowledge management for several salient reasons. The SMEs have the advantage to build strong infrastructure of knowledge management system due to availability and quick of resources, while in large organizations spend inordinate amount of resources on building, managing and develop technology artefact for knowledge management (Desouza and Awazu, 2006).

The intervention of recruitment and selection is one of the most important HRM processes with the greatest influence on implementing lean tools (Yang, 2006). A strong organisational culture with shared core values can be identified as being of importance for a successful lean implementation. An HR lever that has attracted a particularly high level of attention in recent years is employee selection. Selection has been elevated in the list of key HR activities (Buchanan et al., 2007; Leat and El-Kot, 2007; Su and Yang, 2015). Various key HRM levers have been employed, but viewing recruitment and selection activities as integrated key tasks for organisations has been chief among them. The recruitment strategy envisioned by the recruiting management team is to break through current hiring practices with certain quality/quantity at the right time. The objectives of this enhancement are identified as meeting the hiring target of the HR plan in time (Macduffie, 1995; Yew Wong, 2005; Ismail Salaheldin, 2009; Arshida, 2012; Hietschold, Reinhardt and Gurtner, 2014; Lande, Shrivastava and Seth, 2016). Health and safety climate will improve the infrastructure for the organizational and increasing the level of quality inspection by providing all the requirements such as measures to deal with emergencies and accidents, including adequate first-aid arrangements; provide adequate personal protective clothing and equipment without cost to the worker (Hsa, 2006; Alli, 2008; Longoni et al., 2013). In addition to this, applying feedback system the quality of the inspection employee suggestions, employee needs, infrastructure of the workshop and close the gap between the employee and the top management (Tsang and Antony, 2001; Folkman, 2010; Levinson, 2011; Godinho Filho, Ganga and Gunasekaran, 2016; McLean, Antony and Dahlgaard, 2017). 
Training and education is the most factors affecting the journey of LI, studies of employee needs rates help employers identify where HR interventions may be appropriate (Wright and McMahan, 1992; Macduffie, 1995; Bhasin and Burcher, 2006; Leat and El-Kot, 2007; Ali, 2010; Su and Yang, 2015; Laureani and Antony, 2016b). Also, training and education will change the employee attitude and their behaviour by increasing their knowledge, and will affected positively the sustain of continuous improver, an essential step. The training program should be part of the quality policy where the responsibilities, organization, needs, monitoring and assessing of results are essential in the improvement cycle (Yew Wong, 2005; Achanga et al., 2006c; Stanleigh, 2008; Jeyaraman and Kee Teo, 2010; Arshida, 2012; Desai, Antony and Patel, 2012; Deros, 2014; Laureani and Antony, 2016b; Albliwi et al., 2017). In addition, hiring an expert to train and improve the work will enhance the sustain of continuous improvement by involve the consults and improving the training among the employee (Nofal, Omaim and Zairi, 2005; Achanga et al., 2006c; Salem et al., 2006; Barisic and Bozicevic, 2013; Al-najem, 2014; Mohamed Aichouni, Noureddine Ait Messaoudene, 2014).

Once the commitment from top management is present, quality training should be continuously performed, providing the intervention required top management and leadership commitment to demonstrated in the form of developing clear vision, ensuring sufficient financial resources, implement database system, external and internal support, feedback system and providing strategic leadership (Tsang and Antony, 2001; DeTienne and Koberg, 2002; Achanga et al., 2006c; Nordin et al., 2012; Albliwi et al., 2014b; Lam and Rahma, 2014; Asnan, Nordin and Othman, 2015). Deflorin and Scherrer-Rathje (2011) concluded that high level of management commitment is characterised by credibility, consistency, and support. Lack of commitment may lead to issues such as limited access to resources, unusual delay in decision-making process, and ineffective flow of communication (Kundu and Manohar, 2012). These perspectives are in line with the research literature and data gathering which has totally emphasised the importance of top management commitment and support in adopting lean successfully (Achanga et al. 2006; Barraza and Ramis-Pujol, 2010; Coronado and Antony 2002; Crute et al. 2003; Dora et al. 2012; Scherrer-Rathje et al. 2009; Timans et al. 2012). Top management must respect employees' efforts and work to create interest in the implementation and communicate the change to all people in the company. Scherrer- Rathje et al. 2009 stated that in the absence of management commitment employees may not realise the importance of lean, which in turn lead to employee not being totally interested in lean efforts, which will negatively contribute to the lean success. 


\section{Limitation of the research}

The findings of this study are limited in terms of generalisability to SMEs, as the study mainly considered SMEs in KSA, and excluded large firms. Another limitation of this study is the small sample size; the author faced difficulty in convincing a larger number of companies to participate and could not cover the whole manufacturing sector in KSA due to a lack of time and interest from many firms, plus the fact that some firms did not fit the criteria. There is also a lack of information and published studies regarding KSA manufacturing industries; further, there is an absence of research regarding LI within GCC countries, and this meant that it was not possible to compare the findings with those of other researchers. In this study a semistructured interview technique was adopted, along with other data collection methods. Semistructured interviews and focus group may lead to bias, however different techniques were employed in order to keep this bias limited. Furthermore, because a questionnaire was used in this study, the responses from the respondents might not be completely accurate, as for some participants the subject may not have been of interest, and they may have only completed the survey as a favour, or out of politeness, which would have resulted in misleading answers. By using different techniques, it is believed that an accurate picture of SMEs has been obtainedthough this is not certain. In addition, the questionnaire developed based on the seven themes has internal validity. This assessment instrument was not intended to provide a rigorously reliable and externally valid measure of the lean culture. The objective was to obtain an estimate of the team's perception of the lean culture in comparison to an ideal position.

The themes that have emerged from stage 1 of the research refer to that part of the organizational culture that relates to lean implementation. They do not and are not intended to represent a complete picture of the organizational culture of the SMEs. The themes do not exist as stand-alone entities, but coexist as representations of the lean enabling or inhibiting culture in the SMEs. The data gathered relate to lean implementation, and cannot be considered exhaustive. A decision was taken to stop any further refining of the themes after two workshops. Whilst there may have been the opportunity to further refine the themes, the dynamic perspective of the organizational culture suggests that dwelling on refining data developed through a grounded methodology is less useful the later it is done. The organizational culture is continuously evolving, as the artefacts, values and underlying beliefs influence each other. The nature of this research was very participative and the very fact of beginning to talk about lean implementation and engage the participants in a process of discussing and refining its perspective of this culture means that its initial views had developed 
from the early stages of the research. As time progressed this involvement it had an influence on its values and underlying beliefs, thus changing the lean culture. Too much time spent on introspection was likely to yield a view that is significantly outdated and therefore less valid.

The framework identified from literature and data gathering were evaluated from the perspective of being relevant to changing the participants lean culture. The framework suggested are contingent to this research, although their foundation is in management in general. The framework examined cannot be considered as exhaustive. Those identified potentially create aspects of the desired lean culture. They act together to have an effect on the lean culture of the group, but cannot be considered to act independently of each other. There are likely to be other interventions that also act to develop the desired culture. The outcome of applying the SMEs set of interventions to another organization would be dependent upon the existing position of the lean culture. The suggested framework may have some applicability in other mature SMEs organizations, but it would be pertinent to gauge the issues that are inhibiting lean culture in these organizations before suggesting suitable remedies. However, some of the research described in this report may be of benefit to similar organizations struggling with a lack of LI capability. Further research would be required to test the extent to which the proposed framework has widespread applicability. In addition, due to time constraints it was not possible to validate the framework in SMEs who have already implemented LI to use. Finally, the findings of this study are limited in terms of generalisability to SMEs, as the study mainly considered manufacturing sector in KSA, and excluded ANY other sector firms (i.e. services sector).

\section{Future research}

Due to its exploratory nature, this study highlights a number of avenues for further empirical research; as a first step, the framework needs to be applied to successful lean implementation within SMEs to use it as a valid. In addition, the main opportunity for further research is in observing the impact of the framework implemented over time on the development of lean culture. This study has not covered all the manufacturing sectors within the Saudi Arabia context, and it is important to apply it to sectors such as food and beverages; textiles, clothing and leather; wood and wood products; furniture, etc. Increasing the sample size would be another avenue by which to provide more accurate results in the future. To build theory it is necessary to overlap the data analysis with data collection. A study of this type produces large volumes of rich data. The forced comparisons create new categories and concepts (Eisenhardt, 
1989). Overlapping this study with similar studies in other mature small organizations would add a broader range of data and allow more comparisons to be drawn. Furthermore, Arab countries - and more precisely the GCC region - share many values, traditions and cultural aspects with Saudi Arabia, so finding out the LI for firms in these countries would add a great deal of richness to the lean system literature. Moreover, Future research is needed to explore the role of top management across a range of KSA companies in order to find out why there has been a lack of commitment and support for lean implementation to be successful. In addition, the influences of the family owners should be studied in order to explore how this factor affects the capabilities of lean implementation. Primarily, the most significant opportunity for additional research is the framework to be tested in a real environment. Also, applying AHP (analytic hierarchy process) to supplement the purely qualitative approach.

\section{Conclusion}

Research objective was to develop a framework to improve Lean implementation into small and medium enterprise manufacturing organisations in Saudi Arabia by leveraging aspects of Organizational Culture. In stage one, the research takes grounded theory approach, conducting semi-structure interview. The data from semi-structure interview has been analysis. In addition, conducted focus group activity to develop a series if aspects and develop themes, seven themes were identified which represented aspects lean culture that related to lean implementation, these themes were developed throw focus group activity. In stage Two, provided triangulation of the grounded research findings from stage One and in addition, provided an assessment of the extant position of the SMEs participant's lean culture in facilitating lean implementation. This provided a starting point for developing a framework of interventions suitable for moving the organizational culture to be more supportive of lean implementation. Stage Three, suggested a series of interventions that were suitable for SMEs, a series of interventions literature review was again related for appropriate intervention and compare contrast with literature, data gathering was blind then with literature review then conflated as a word use literature and data gathering to develop a series of intervention to facilitate lean in terms of developing aspects of a lean culture. The interventions identified from literature and data gathering were evaluated from the perspective of being relevant to changing the SMEs lean culture. A key aspect of the interventions is the role of the family member and top management commitment. This leadership from the top of the company is essential to ensure resources and support for lean implementation are made available, but more importantly, it is managing the 
influences of the family owners. Contribution to the knowledge the contribution of this study to the body of knowledge on LI is expected to be significant. Considering the nonexistence of LI by leveraging aspects of organizational culture studies within the KSA context, this study has added a new dimension as it has shown the LI within SMEs and identified the factors that are preventing KSA firms from being lean. Moreover, there has been a lack of research regarding LI within SMEs context to date, especially in the Arab world where no studies have considered LI within SMEs. This study contributes to the literature on lean in the developingcountry context, especially in the Arab world, as Arab countries share many similarities in terms of culture and other traits, and the findings of this study can be used the framework for other Arab countries. It also contributes to knowledge about the failure of lean implementation. Several researchers (e.g., Ballé, 2005; T. C. Papadopoulou and Özbayrak, 2005; Emilliani, 2008) have stated that despite the huge benefits of lean there are a large number of failure stories in relation to lean implementation. To avoid failure, there is a need to understand the organisation's ability to adopt clean, and to understand the requirements for it; the framework developed in this study will enable organisations to evaluate their abilities before attempting lean, create an environment of lean culture that facilitate lean implementation and to understand the requirements as the framework can be used.

In addition, the research contributes to knowledge concerning aspects of organizational culture that facilitate lean implementation. This knowledge is transdisciplinary and adds to the domains of lean implementation, organizational culture and lean culture. The researcher has deployed a grounded participative methodology, within "live" SMEs manufacturing sector teams to surface key aspects of lean culture. The research can be considered to be a live experimental approach to organizational development. This approach adds to the theoretical knowledge of organizational development for transformational change as the research is participative, it is well placed in its potential for developing theory that will be relevant to practice (Huxham and Vangen, 2003). This participative approach to developing knowledge of the members' perceptions of lean culture and on creating lean implementation capability from an insider perspective contributes develop framework. Moreover, due to the diversity of data-collection sources used, this study added new insight to the inhibitors faced by SMEs which may not enable them to implement lean, and addressed the source of those inhibitors. Finally, the framework does not currently exist in the literature, which facilitate lean implementation by leveraging aspects of $\mathrm{OC}$ relating to SMEs presented here thus represents a unique effort in the area of LI. 
This research includes insider action research content. This inevitably had an influence on the response of participants to interviews, focus group sessions and discussions about the research activities. The methodology adopted used triangulation in the form of established assessment tools and a journal kept by the researcher as a method of validating what had been developed in the participative work with the team. This brand of insider participative action research is less usual. The methodological approach to this research required the experiential involvement of the researcher, the absence of a priori analytical categories and intent to understand a situation (Evered and Louis, 1981). The triangulation of the findings developed from a grounded methodology through observations and assessments adds to the validity of the framework developed. The approach adopted would have applicability in other situations in which the researcher in the role of practitioner has similar opportunity to influence the responses from the research subjects. There is therefore a contribution to methodology for this form of action research. Practitioner contribution, for practitioners, the research findings can be used to help understand aspects of organizational culture that facilitate lean implementation. Introduction of an implementation framework of cultural aspects that facilitate Lean implementation within small and medium sized manufacturing organisation in Saudi Arabia. The framework influencing lean implementation has a degree of generalizability outside the specific context of SMEs in Saudi Arabia. The framework represents aspects of organizational culture that influence lean implementation. The framework starting template for evaluating other organizations' lean cultures. Although the research will be contextual to SMEs, there are features that may be relevant to other SMEs struggling with a lack of lean culture. As Parker states (2000: 222), 'all organizational cultures are unique, yet at the same time they share similar features'. Developing lean implementation capability is of interest to a growing number of firms. The framework suggested as part of the research is designed to develop lean culture to facilitate lean implementation. The framework is based on empirical examples and addresses the reduction of the gap between the extant and ideal position of the lean culture. For practitioners, the contribution is therefore in what lean culture "looks like" and "how to get there" (Hargadon, 2003). This research contributes to the area of lean implementation in SMEs manufacturing sector, in designing a framework to create a lean culture within a larger incremental culture. Moreover, the findings of this research can arguably be generalised to SMEs in KSA, as several interviews were conducted with firms in KSA to identify the reasons why LI implementation has been delayed or struggle, which means that a general view of the SMEs was obtained, rather than data only on those visited. Moreover, the framework is 
intended to aid SMEs practitioners in carrying out impact assessment of lean manufacturing implementation at the early implementation stage.

\section{References}

Achanga, P., Shehab, E., Roy, R. and Nelder, G. (2006) 'Critical success factors for lean implementation within SMEs', Journal of Manufacturing Technology Management. Edited by S. Saad, 17(4), pp. 460-471. doi: 10.1108/17410380610662889.

Adler, P. and Cole, R. (1995) Designed for learning: A tale of two auto plants. Edited by Sloan Management Review.

Al-najem, M. (2014) Investigating the factors affecting readiness for lean system adoption within Kuwaiti small and medium- sized manufacturing industries. University of Portsmouth.

Al-Najem, M., Dhakal, H. and Bennett, N. (2012) 'The role of culture and leadership in lean transformation: a review and assessment mode', International Journal of Lean Thinking, 3(1), pp. $119-138$.

AL-Najem, M., Dhakal, H., Labib, A. and Bennett, N. (2013) 'Lean readiness level within Kuwaiti manufacturing industries', International Journal of Lean Six Sigma, 4(3), pp. 280-320. doi:

10.1108/IJLSS-05-2013-0027.

Albliwi, S. A., Antony, J., Arshed, N. and Ghadge, A. (2017) 'Implementation of Lean Six Sigma in Saudi Arabian organisations', International Journal of Quality \& Reliability Management, 34(4), pp. 508-529. doi: 10.1108/IJQRM-09-2015-0138.

Albliwi, S., Antony, J., Abdul Halim Lim, S. and van der Wiele, T. (2014) 'Critical failure factors of Lean Six Sigma: a systematic literature review', International Journal of Quality \& Reliability Management, 31(9), pp. 1012-1030. doi: 10.1108/IJQRM-09-2013-0147.

Allen, N. J. and Meyer, J. P. (1993) 'Organizational commitment: Evidence of career stage effects?', Journal of Business Research, 26(1), pp. 49-61. doi: 10.1016/0148-2963(93)90042-N.

Alshahrani, S. a. and Alsadiq, A. J. (2014) 'Economic Growth and Government Spending in Saudi Arabia: an Empirical Investigation', IMF Working Papers, 14(3), p. 1. doi:

$10.5089 / 9781484348796.001$.

Alstrup, L. (2000) 'Coaching continuous improvement in small enterprises', Integrated Manufacturing Systems, 11(3), pp. 165-170. doi: 10.1108/09576060010320371.

Angelis, J., Conti, R., Cooper, C. and Gill, C. (2011) 'Building a high-commitment lean culture', Journal of Manufacturing Technology Management, 22(5), pp. 569-586. doi:

10.1108/17410381111134446.

Angen, M. (2000) Evaluating interpretive inquiry: Reviewing the validity debate and opening the dialogue, Qualitative health research. SAGE Publications.

Annells, M. (1996) 'Grounded Theory Method: Philosophical Perspectives, Paradigm of Inquiry, and Postmodernism’, Qualitative Health Research, 6(3), pp. 379-393. doi: $10.1177 / 104973239600600306$

Babbie, E. (2015) The practice of social research. Wadsworth Cengage Learning.

Baidoun, S. (2004) 'The implementation of TQM philosophy in Palestinian organization: a proposed non-prescriptive generic framework', The TQM Magazine, 16(3), pp. 174-185. doi:

$10.1108 / 09544780410532909$. 
Ballé, M. (2005) 'Lean attitude', Manufacturing Engineer, 84(2), pp. 14-19. doi: 10.1049/me:20050202.

Bardot, S. (2013) 'Background on Work Life in the United Arab Emirates and Other Gulf Countries (Gulf Cooperation Council)', Compensation \& Benefits Review, 45(1), pp. 21-25. doi: $10.1177 / 0886368713485040$.

Berger, A. (1997) 'Continuous improvement and kaizen : standardization and organizational designs', Integrated Manufacturing Systems. MCB UP Ltd, 8(2), pp. 110-117. doi: $10.1108 / 09576069710165792$.

Bhamra, R., Dani, S. and Bhamra, T. (2011) 'Competence understanding and use in SMEs: a UK manufacturing perspective', International Journal of Production Research, 49(10), pp. 2729-2743. doi: $10.1080 / 00207541003738873$.

Bhamu, J. and Singh Sangwan, K. (2014a) 'Lean manufacturing: literature review and research issues', International Journal of Operations \& Production Management, 34(7), pp. 876-940. doi: 10.1108/IJOPM-08-2012-0315.

Bhamu, J. and Singh Sangwan, K. (2014b) 'Lean manufacturing: literature review and research issues', International Journal of Operations \& Production Management. Emerald Group Publishing Ltd., 34(7), pp. 876-940. doi: 10.1108/IJOPM-08-2012-0315.

Bhasin, S. and Burcher, P. (2006) 'Lean viewed as a philosophy', Journal of Manufacturing Technology Management, 17(1), pp. 56-72. doi: 10.1108/17410380610639506.

Black, A. (2011) The History of Islamic Political Thought: From the Prophet to the Present. 2nd edn. Edinburgh University Press.

Bogdan, R. and Biklen, S. K. (2007) Qualitative Research for Education: An Introduction to Theories and Methods. Pearson A \& B. Available at: https://books.google.com/books?id=27JOPgAACAAJ\&pgis=1.

Brannen, M. Y. (2015) The Routledge Companion to Cross-Cultural Management. Edited by \& S. T. Holden, S. Michailova. Routledge.

Browning, T. R. and Heath, R. D. (2009) 'Reconceptualizing the effects of lean on production costs with evidence from the F-22 program', Journal of Operations Management, 27(1), pp. 23-44. doi: 10.1016/j.jom.2008.03.009.

Bryman, A. and Bell, E. (2015) Business Research Methods. New York: Oxford University Press.

Burke, L. and Logsdon, J. M. (1996) 'How Corporate Social Responsibility Pays Off', Long Range Planning, 29(4), pp. 495-502. doi: 10.1016/0024-6301(96)00041-6.

Cameron, K. S. (1994) 'Strategies for successful organizational downsizing', Human Resource Management, 33(2), pp. 189-211. doi: 10.1002/hrm.3930330204.

CARPENTER, C. and SUTO, M. (2008) Qualitative research for occupational and physical therapists : a practical guide - Google Scholar. Oxford, : Blackwell Publishing. Available at: https://scholar.google.co.uk/scholar?q=Qualitative + research + for + occupational + and + physical + therapi sts $+\% 3 \mathrm{~A}+\mathrm{a}+$ practical + guide $\&$ btnG $=\& \mathrm{hl}=$ en\&as_sdt $=0 \% 2 \mathrm{C} 5$.

Chandler, G. N. and Hanks, S. H. (1994) 'Market attractiveness, resource-based capabilities, venture strategies, and venture performance', Journal of Business Venturing, 9(4), pp. 331-349. doi: 10.1016/0883-9026(94)90011-6.

Coghlan, D. and Brannick, T. (2014) Doing action research in your own organization. Sage. Available at: https://books.google.co.uk/books?hl=en\&lr=\&id=c_CGAwAAQBAJ\&oi=fnd\&pg=PP1\&dq=Doing+ Action+Research + in + Your + Own+Organization\&ots=_MSQ5wrb5I\&sig=llq7nPn2ECO8yp-TAlWN- 
MeTZug.

Cooney, R. (2002) 'Is “lean” a universal production system?', International Journal of Operations \& Production Management. MCB UP Ltd, 22(10), pp. 1130-1147. doi: 10.1108/01443570210446342.

Cooper, R. G. (1999) 'The Invisible Success Factors in Product Innovation', Journal of Product Innovation Management, 16(2), pp. 115-133. doi: 10.1111/1540-5885.1620115.

Corbett, S. (2007) 'Beyond manufacturing: The evolution of lean production', McKinsey Quarterly, (3), pp. 94-96.

Corbin, J. and Strauss, A. (1990) Basics of qualitative research: Grounded theory procedures and techniques, Basics of qualitative research. Sage.

Creswell, J. (2013) Research design: Qualitative, quantitative, and mixed methods approaches. SAGE Publications.

Crofton, C. G. and Dale, B. G. (1996) 'The Difficulties Encountered in the Introduction of Total Quality Management: A Case Study Examination', Quality Engineering. Taylor \& Francis Group, 8(3), pp. 433-439. doi: 10.1080/08982119608904645.

Crossan, M. M., Lane, H. W. and White, R. E. (1999) 'AN ORGANIZATIONAL LEARNING FRAMEWORK: FROM INTUITION TO INSTITUTION.', Academy of Management Review, 24(3), pp. 522-537. doi: 10.5465/AMR.1999.2202135.

Cruft, R. (2005) 'Human Rights, Individualism and Cultural Diversity', Critical Review of International Social and Political Philosophy. Routledge, 8(3), pp. 265-287. doi: $10.1080 / 13698230500187151$.

Cusumano, M. (1994) 'The Limits of" Lean”", Sloan management review, 34(4), p. 27.

Dartey-Baah, K. (2013) 'The Cultural Approach to the Management of the International Human Resource: An Analysis of Hofstede's Cultural Dimensions', International Journal of Business Administration, 4(2), pp. 39-45. doi: 10.5430/ijba.v4n2p39.

Davis, T. (1985) 'Managing culture at the bottom', Gaining control of the corporate culture, pp. 163183.

Dey, I. (1999) Grounding Grounded Theory: Guidelines for Qualitative Inquiry. Academic Press.

Dick, B. (2006) 'Grounded theory: a thumbnail sketch'.

Dodgson, M. (1993) 'Organizational learning: a review of some literatures', Organization studies, 14(3), pp. 375-394. Available at: http://oss.sagepub.com/content/14/3/375.short (Accessed: 26 April 2016).

Dombrowski, U., Crespo, I. and Zahn, T. (2010) 'Adaptive Configuration of a Lean Production System in Small and Medium-sized Enterprises', Production Engineering, 4(4), pp. 341-348. doi: 10.1007/s11740-010-0250-5.

Dorota Rymaszewska, A. (2014) 'The challenges of lean manufacturing implementation in SMEs', Benchmarking: An International Journal, 21(6), pp. 987-1002. doi: 10.1108/BIJ-10-2012-0065.

Eisenhardt, K. M. (1989) 'Building Theories from Case Study Research.', Academy of Management Review, 14(4), pp. 532-550. doi: 10.5465/AMR.1989.4308385.

Eklund, J. (2000) 'Towards a Framework for Quality of Interactions between Humans, Technology and Organization', Proceedings of the Human Factors and Ergonomics Society Annual Meeting, 44(12), pp. 2-463-2-466. doi: 10.1177/154193120004401207.

European Commission (2011) (no date) Guide to EU definition of SME, 2011. Available at: $\mathrm{http} / /$ ec.europa.eu/growth/smes/business-friendly-environment/sme-definition/index_en.htm 
(Accessed: 15 May 2015).

Fok-yew, O. and Ahmad, H. (2014) 'The Effect of Change Management on Operational Excellence moderated by Commitment to Change : Evidence from Malaysia', International Journal of Innovation and Applied Studies, 9(2), pp. 615-631.

Francesco, A. and Gold, B. (2005) International organizational behavior: Text, readings, cases, and skills. Second Edi. New Jersey: Pearson Prentice Hall.

Fredriksson, R., Barner-Rasmussen, W. and Piekkari, R. (2006) 'The multinational corporation as a multilingual organization', Corporate Communications: An International Journal. Emerald Group Publishing Limited, 11(4), pp. 406-423. doi: 10.1108/13563280610713879.

Gibson, C. B. and Zellmer-Bruhn, M. E. (2001) 'Metaphors and Meaning: An Intercultural Analysis of the Concept of Teamwork', Administrative Science Quarterly, 46(2), p. 274. doi: 10.2307/2667088.

Glaser, B. and Strauss, A. (1967) ‘A.(1967). The discovery of grounded theory’, Strategies for qualitative research. London: Weidenfeld ....

Golden-Biddle, K. and Locke, K. (2007) Composing qualitative research. 2nd edn. London: Sage Publications, Inc. Available at:

https://books.google.co.uk/books?hl=en\&lr=\&id=2nn0ZJ8ouB8C\&oi=fnd\&pg=PR7\&dq=Composing + qualitative + research\&ots $=2 \mathrm{aGLfO} 9 \mathrm{hEd} \&$ sig=iIP3SOEGkD-ewVpl7jxtVjCBLto.

Goldstein, L. J. (1957) 'On Defining Culture', American Anthropologist, 59(6), pp. 1075-1081. doi: 10.1525/aa.1957.59.6.02a00110.

Goulding, C. (1998) 'Grounded theory: the missing methodology on the interpretivist agenda', Qualitative Market Research: An International Journal, 1(1), pp. 50-57. doi: 10.1108/13522759810197587.

Goulding, C. (2005) 'Grounded theory, ethnography and phenomenology', European Journal of Marketing. Edited by N. Lee, 39(3/4), pp. 294-308. doi: 10.1108/03090560510581782.

Government, S. A. (2015) Saudi Arabia beyond oil: The investment and productivity transformation, McKinsey \& Company. Available at: http://vision2030.gov.sa/en/node/8.

Graham-jones, J. and Muhareb, T. M. Al (2015) 'Using Lean Six-Sigma in the Improvement of Service Quality at Aviation Industry : Case Study at the Departure Area in KKIA Using Lean SixSigma in the Improvement of Service Quality at Aviation Industry : Case Study at the Departure Area in KKIA', (MARCH 2014).

Graves, C. and Thomas, J. (2006) 'Internationalization of Australian family businesses: A managerial capabilities perspective', Family Business Review, 19(3), pp. 207-224. doi: 10.1111/j.17416248.2006.00066.x.

Guba, E. and Lincoln, Y. (1989) Fourth generation evaluation. Sage.

Guba, E. and Lincoln, Y. (1994) 'Competing paradigms in qualitative research', Handbook of qualitative research, pp. 105-117.

Gupta, S., Sharma, M. and Sunder M., V. (2016) 'Lean services: a systematic review', International Journal of Productivity and Performance Management, 65(8), pp. 1025-1056. doi: 10.1108/IJPPM02-2015-0032.

Gupta, V., Acharya, P. and Patwardhan, M. (2013) 'A strategic and operational approach to assess the lean performance in radial tyre manufacturing in India', International Journal of Productivity and Performance Management, 62(6), pp. 634-651. doi: 10.1108/IJPPM-Jun-2012-0057.

Gwet, K. (2002) 'Kappa statistic is not satisfactory for assessing the extent of agreement between raters', Statistical methods for inter-rater reliability assessment, (1). 
Hall, A. (1995) Principles and practices of Lean manufacturing. University of Kentucky, Lexington.

Halliday, F. (2000) 'Global Governance: Prospects and Problems', Citizenship Studies. Taylor \& Francis Group, 4(1), pp. 19-33. doi: 10.1080/136210200110003.

Held, D. and McGrew, A. (2000) The global transformations reader. Available at: http://www.researchgate.net/profile/David_Held2/publication/200456939_Global_Transformations_P olitics_Economics_and_Culture/links/00b7d529782f76ab2d000000.pdf.

Hietschold, N., Reinhardt, R. and Gurtner, S. (2014) 'Measuring critical success factors of TQM implementation successfully - a systematic literature review', International Journal of Production Research. Taylor \& Francis, 52(21), pp. 6254-6272. doi: 10.1080/00207543.2014.918288.

Hines, P., Holweg, M. and Rich, N. (2004) 'Learning to evolve', International Journal of Operations \& Production Management. Emerald Group Publishing Limited, 24(10), pp. 994-1011. doi: $10.1108 / 01443570410558049$.

Hofstede, G., Hofstede, G. and Minkov, M. (1991) Cultures and organizations: Software of the mind. London: McGraw-Hill. Available at: http://citeseerx.ist.psu.edu/viewdoc/download?doi=10.1.1.446.3598\&rep=rep1\&type=pdf.

Hoftstede, G. (1980) ‘Culture's consequences', Sage, Beverly Hills, CA.

Hopp, W. J. and Spearman, M. L. (2004) 'To Pull or Not to Pull: What Is the Question?', Manufacturing \& Service Operations Management, 6(2), pp. 133-148. doi: $10.1287 / \mathrm{msom} .1030 .0028$.

Hu, Q., Mason, R., Williams, S. J. and Found, P. (2015) 'Lean implementation within SMEs: a literature review', Journal of Manufacturing Technology Management, 26(7), pp. 980-1012. doi: 10.1108/JMTM-02-2014-0013.

Huxham, C. and Vangen, S. (2003) 'Researching Organizational Practice through Action Research: Case Studies and Design Choices', Organizational Research Methods, 6(3), pp. 383-403. doi: $10.1177 / 1094428103254454$.

Im, J. H. and Lee, S. M. (1989) 'Implementation of Just-in-time Systems in US Manufacturing Firms', International Journal of Operations \& Production Management, 9(1), pp. 5-14. doi: 10.1108/EUM0000000001213.

Inman, R. A. and Mehra, S. (1990) 'The Transferability of Just-in-Time Concepts to American Small Businesses', Interfaces, 20(2), pp. 30-37.

James-Moore, S. M. and Gibbons, A. (1997) 'Is lean manufacture universally relevant? An investigative methodology', International Journal of Operations \& Production Management. MCB UP Ltd, 17(9), pp. 899-911. doi: 10.1108/01443579710171244.

Karim, A. and Arif-Uz-Zaman, K. (2013) 'A methodology for effective implementation of lean strategies and its performance evaluation in manufacturing organizations', Business Process Management Journal, 19(1), pp. 169-196. doi: 10.1108/14637151311294912.

Karim, M. A., Aljuhani, M., Duplock, R. and Yarlagadda, P. (2011) 'Implementation of Lean Manufacturing in Saudi Manufacturing Organisations: An Empirical Study', Advanced Materials Research, 339, pp. 250-253. doi: 10.4028/www.scientific.net/AMR.339.250.

Kochan, T., Lansbury, R. and Macduffie, J. (1997) After lean production: Evolving employment practices in the world auto industry. New York: Cornell University Press.

Koeningsaecker, G. (2005) 'Leadership and the lean transformation', Manufacturing Engineering, 135(5), pp. 7-11.

Kolb, S. M. (2012) 'Grounded Theory and the Constant Comparative Method : Valid Research 
Strategies for Educators', Journal of Emerging Trends in Educational Research and Policy Studies, 3(1), pp. 83-86. Available at: http://jeteraps.scholarlinkresearch.com/articles/Grounded Theory and the Constant Comparative Method.pdf.

Kovacheva, A. V. (2010) 'Challenges in Lean implementation Successful transformation towards Lean enterprise’, University of Aarhus, (January), pp. 1-58.

Kuran, T. (1993) 'Ch14:The Economic Impact of Islamic Fundamentalism. In T. Kuran, The Economic Impact of Islamic Fundamentalism’, pp. 302-341.

Lathin, D., E, L., N, A., Arbor, A., Mitchell, R., E, L. and N, A. (2001) 'Lean manufacturing: techniques, people and culture', In ASQ World Conference on Quality and Improvement Proceedings, p. 321.

Lazăr, L. (2010) 'Communication as defining dimension of culture', Acta Universitatis Danubius. Communicatio, 2(1), pp. 43-47.

LeCompte, M. and Goetz, J. (1982) 'Problems of reliability and validity in ethnographic research', Review of educational research, 52(1), pp. 31-60. Available at: http://rer.sagepub.com/content/52/1/31.short.

Lewis, M. A. (2000) 'Lean production and sustainable competitive advantage', International Journal of Operations \& Production Management, 20(8), pp. 959-978. doi: 10.1108/01443570010332971.

Liamputtong, P. and Ezzy, D. (2009) Qualitative research methods. Oxford: Oxford University Press.

Lietz, C. and Zayas, L. (2010) 'Evaluating qualitative research for social work practitioners', Advances in Social Work, pp. 188-202.

Liker, J. (1997) Becoming lean: Inside stories of US manufacturers. Productivity Press.

Lincoln, Y. and Guba, E. (1985) 'Naturalistic inquiry'. Available at:

https://scholar.google.co.uk/scholar?q=Naturalistic+inquiry.\&btnG $=\& h l=e n \& a s \_s d t=0 \% 2 C 5 \# 0$ (Accessed: 10 September 2015).

Locke, K. (2001) Grounded theory in management research. Sage. Available at: https://books.google.co.uk/books?hl=en\&lr=\&id=OcDWB-

rWvWUC\&oi=fnd\&pg $=$ PR7\&dq $=$ Grounded + Theory + in + Management + Research\&ots $=$ XpNKmQ 8n\&sig=S_7FYKQRplq1SRwd_aSjzm5c3VQ.

Löfving, M., Säfsten, K. and Winroth, M. (2014) 'Manufacturing strategy frameworks suitable for SMEs', Journal of Manufacturing Technology Management, 25(1), pp. 7-26. doi: 10.1108/JMTM-082012-0081.

Lundestad, G. (1997) 'East, West, North, South: major developments in international politics, 19451996'.

MacDuffie, J. P. and Helper, S. (1997) 'Creating Lean Suppliers: Diffusing Lean Production through the Supply Chain', California Management Review. California Management Review, 39(4), pp. 118 151.

Mason, J. (1996) Qualitative Researching, Qualitative research. Sage. Available at: $\mathrm{http}: / /$ qrj.sagepub.com/content/6/1/9.short.

Maxwell, J., Briscoe, F., Schenk, B. and Rothenberg, S. (1998) 'Case study: Honda of America Manufacturing, Inc.: Can lean production practices increase environmental performance?', Environmental Quality Management, 8(1), pp. 53-61. doi: 10.1002/tqem.3310080107.

Miles, M. and Huberman, A. (1994) Qualitative data analysis: An expanded sourcebook. Sage. Available at:

https://scholar.google.co.uk/scholar?hl=en\&q=Qualitative+data+analysis\%3A+An+expanded + source 
+ book\&btnG $=\&$ as_sdt $=1 \% 2 \mathrm{C} 5 \&$ as_sdtp $=\# 0$ (Accessed: 16 April 2016).

Moosa, K. and Sajid, A. (2010) 'Critical analysis of Six Sigma implementation', Total Quality Management and Business Excellence, 21(7), pp. 745-759. doi: 10.1080/14783363.2010.483100.

Naor, M., Goldstein, S. M., Linderman, K. W. and Schroeder, R. G. (2008) 'The Role of Culture as Driver of Quality Management and Performance: Infrastructure Versus Core Quality Practices*', Decision Sciences, 39(4), pp. 671-702. doi: 10.1111/j.1540-5915.2008.00208.x.

Narasimhan, R., Kull, T. J. and Nahm, A. (2012) 'Alternative relationships among integrative beliefs, time-based manufacturing and performance', International Journal of Operations \& Production Management. Emerald Group Publishing Limited, 32(4), pp. 496-524. doi: $10.1108 / 01443571211223112$.

Newman, K. and Nollen, S. (1996) 'Culture and congruence: The fit between management practices and national culture', Journal of international business studies, 27(4), pp. 753-779. Available at: http://www.jstor.org/stable/155511 (Accessed: 16 April 2016).

Pakdil, F. and Leonard, K. M. (2015a) 'The effect of organizational culture on implementing and sustaining lean processes', Journal of Manufacturing Technology Management, 26(5), pp. 725-743. doi: 10.1108/JMTM-08-2013-0112.

Pakdil, F. and Leonard, K. M. (2015b) 'The effect of organizational culture on implementing and sustaining lean processes', Journal of Manufacturing Technology Management, 26(5), pp. 725-743. doi: 10.1108/JMTM-08-2013-0112.

Papadopoulou, T. C. and Özbayrak, M. (2005) 'Leanness: experiences from the journey to date', Journal of Manufacturing Technology Management, 16(7), pp. 784-807. doi: $10.1108 / 17410380510626196$.

Parker, M. (2000) Organizational Culture and Identity, ILM Superseries.

Patton, M. Q. (2014) Qualitative Research \& Evaluation Methods: Integrating Theory and Practice: Integrating Theory and Practice. SAGE Publications. Available at: https://books.google.com/books?id=-CM9BQAAQBAJ\&pgis=1.

Pingyu, Y. and Yu, Y. (2010) 'A review on lean manufacturing practices in small and medium enterprises', International Journal of Innovation, Management and Technology, 1(2), pp. 220-225.

Podrug, N. (2011) 'Influence of National Culture on Decision-Making Style', South East European Journal of Economics and Business, 6(1), pp. 37-44. doi: 10.2478/v10033-011-0004-0.

Pooyan, B., Napsiah, I. and Zulkiflle, L. (2014) 'Review of Lean Adoption within Small and Medium Sized Enterprises', Advanced Materials Research. Trans Tech Publications, 903, pp. 414-418. doi: 10.4028/www.scientific.net/AMR.903.414.

R. Jadhav, J., S. Mantha, S. and B. Rane, S. (2014) 'Exploring barriers in lean implementation', International Journal of Lean Six Sigma, 5(2), pp. 122-148. doi: 10.1108/IJLSS-12-2012-0014.

Rashid, H. (2010) Human factors effects in helicopter maintenance: proactive monitoring and controlling techniques. Cranfield University.

Sackmann, S. (1991) 'Uncovering culture in organizations', The Journal of applied behavioral science, 27(3), pp. 295-317.

Sackmann, S. (2006) Success factor : corporate culture : developing a corporate culture for high performance and long term competitiveness : six best practices /. Gütersloh : Verlag Bertelsmann Stiftung,

Safety, H. and and Executive (2008) Successful health and safety management., Hse. 
Salem, O., Solomon, J., Genaidy, A. and Minkarah, I. (2006) 'Lean Construction: From Theory to Implementation', Journal of Management in Engineering, 22(4), pp. 168-175. doi:

10.1061/(ASCE)0742-597X(2006)22:4(168).

Saudi Industrial Property Authority (2015) Saudi Industrial Property Authority, MODON. Available at: http://www.modon.gov.sa/en/Pages/default.aspx (Accessed: 20 August 2015).

Schein, E. (1985) 'How culture forms, develops, and changes', Gaining control of the corporate culture, pp. 17-43. Available at:

https://scholar.google.co.uk/scholar?q=How + Culture+Forms $\% 2 \mathrm{C}+$ Develops + and + Changes $\& b t n G=\&$ $\mathrm{hl}=$ en\&as_sdt $=0 \% 2 \mathrm{C} 5 \# 0$.

Schein, E. H. (1984) 'Coming to a New Awareness of Organizational Culture', Sloan Management Review, 25(2), pp. 3-16.

Schneider, S. C. and De Meyer, A. (1991) 'Interpreting and responding to strategic issues: The impact of national culture', Strategic Management Journal, 12(4), pp. 307-320. doi:

10.1002/smj.4250120406.

Shah, R. and Ward, P. T. (2007) 'Defining and developing measures of lean production', Journal of Operations Management, 25(4), pp. 785-805. doi: 10.1016/j.jom.2007.01.019.

Silverman, D. (2006) Interpreting qualitative data: Methods for analyzing talk, text and interaction. 3rd edn. Los Angeles: Sage. Available at:

https://books.google.co.uk/books?hl=en\&lr=\&id=uooz4p82sDgC\&oi=fnd\&pg=PP1\&dq=Interpreting + qualitative + data. + Methods + for + analyzing + talk, + text+and + interaction\&ots $=u$ PWFZmufGR\&sig $=n$ MLeyQ1rm6K-pQQ-QCIsoTgYH6U.

Soriano-Meier, H. and Forrester, P. L. (2002) 'A model for evaluating the degree of leanness of manufacturing firms', Integrated Manufacturing Systems, 13(2), pp. 104-109. doi: 10.1108/09576060210415437.

Srubar, I. (1998) 'Phenomenological Analysis and its Contemporary Significance', Human Studies, 21(2), pp. 121-139. doi: 10.1023/A:1005355921478.

Strauss, A. (1987) Qualitative analysis for social scientists. Cambridge University Press. Available at: https://books.google.co.uk/books?hl=en\&lr=\&id=y16ww5ZsJ0AC\&oi=fnd\&pg=PA109\&dq=Qualitat ive + analysis + for + social + scientists\&ots $=\mathrm{gV} 8 \mathrm{wNShaiS} \&$ sig $=\mathrm{t} 65 \mathrm{cOdLOiuvOImCBO} 87$ UKCYBWI (Accessed: 16 April 2016).

Taj, S. (2008) 'Lean manufacturing performance in China: assessment of 65 manufacturing plants', Journal of Manufacturing Technology Management, 19(2), pp. 217-234. doi:

$10.1108 / 17410380810847927$.

The Telegraph (2012) Council docked Muslim worker's pay for prayer breaks, 2012 Jun 5.

Tilley, J. (2000) ‘Cultural relativism’, Human Rights Quarterly, pp. 501-547.

Timans, W., Antony, J., Ahaus, K. and van Solingen, R. (2011) 'Implementation of Lean Six Sigma in small- and medium-sized manufacturing enterprises in the Netherlands', Journal of the Operational Research Society. Springer Nature, 63(3), pp. 339-353. doi: 10.1057/jors.2011.47.

Trochim, W. and Donnelly, J. (2001) 'Research methods knowledge base'.

Vidal, M. (2007) 'Manufacturing empowerment?'Employee involvement'in the labour process after Fordism', Socio-economic review, 5(2), pp. 197-232. Available at: http://ser.oxfordjournals.org/content/5/2/197.short.

Walker, D. and Myrick, F. (2006) 'Grounded Theory: An Exploration of Process and Procedure', Qualitative Health Research, 16(4), pp. 547-559. doi: 10.1177/1049732305285972. 
Whitfield, K. and Poole, M. (1997) 'Organizing employment for high performance: Theories, evidence and policy', Organization Studies, 18(5), p. 745. Available at:

http://oss.sagepub.com/content/18/5/745.short (Accessed: 26 April 2016).

Wittenberg, G. (1994) 'Kaizen - The many ways of getting better', Assembly Automation, 14(4), pp. 12-17. doi: 10.1108/EUM0000000004213.

Womack, J., \& Jones, D. T. (2003) Lean Thinking: Banish Waste And Create Wealth In Your Corporation. 2nd edn. New York: Simon and Schuster.

Womack, J., Jones, D. and Roos, D. (1990) Machine that changed the world. Simon and Schuster. Available at:

https://books.google.co.uk/books?hl=en\&lr=\&id= n5qRfaNv9AC\&oi=fnd\&pg=PR7\&dq=The+Mach ine + that + Changed + the + World $\&$ ots $=$ cr7kJ2FMy $2 \&$ sig $=$ OOmvICCN8XJ3sUu3oQvVCbCYWkk .

Wong, Y. C., Wong, K. Y. and Ali, A. (2009) 'Key practice areas of lean manufacturing', 2009 International Association of Computer Science and Information Technology - Spring Conference, IACSIT-SC 2009, pp. 267-271. doi: 10.1109/IACSIT-SC.2009.44.

Wood, J. F. (2011) 'An Introduction to Intercultural Communication: Identities in a Global Community (6th Edition)', Journal of Intercultural Communication Research. Routledge, 40(2), pp. 173-175. doi: 10.1080/17475759.2011.581035.

Zargun, S. and Al-Ashaab, A. (2013) 'Critical Success Factors for Lean Manufacturing: A Systematic Literature Review an International Comparison between Developing and Developed Countries', Advanced Materials Research, 845, pp. 668-681. doi: 10.4028/www.scientific.net/AMR.845.668. 


\begin{tabular}{ll}
\hline Definitions of Lean & Reference
\end{tabular}

"The Lean approach percolates into ever wider circles of operations, it ceases to be about the best practice and starts to become a part of the fabric of doing (Corbett, 2007, p. business."

\begin{tabular}{|c|c|}
\hline $\begin{array}{l}\text { "Lean production is based on several key principles: eliminating wasteful } \\
\text { activities, minimising process variability, pursuing continuous process } \\
\text { improvement with employee involvement, devolvement of activities such a } \\
\text { quality inspections and periodic maintenance to line workers and maintaining } \\
\text { synchronised production flow through shop floor visual signals." }\end{array}$ & $\begin{array}{l}\text { (Angelis et al., } \\
2011, \text { p. 569) }\end{array}$ \\
\hline $\begin{array}{l}\text { "Lean production is an integrated socio-technical system whose main } \\
\text { objective is to eliminate waste by concurrently reducing or minimising } \\
\text { supplier, customer and internal variability." }\end{array}$ & $\begin{array}{l}\text { (Shah and Ward, } \\
2007, \text { p. } 791)\end{array}$ \\
\hline $\begin{array}{l}\text { "Production that minimises buffering costs associated with excess lead times, } \\
\text { inventories, or capacity." }\end{array}$ & $\begin{array}{l}\text { (Hopp and } \\
\text { Spearman, 2004; } \\
\text { Angelis et al., } \\
\text { 2011, p. 569) }\end{array}$ \\
\hline $\begin{array}{l}\text { "Lean manufacturing combines the capabilities of the workforce with } \\
\text { organisational techniques to achieve high outcomes with few resources." }\end{array}$ & $\begin{array}{l}\text { (Salem et al., } \\
\text { 2006, p. 169) }\end{array}$ \\
\hline
\end{tabular}


Aspects of organizational culture

\begin{tabular}{|c|c|c|c|c|c|c|c|}
\hline 1. & Job description & 2. & $\begin{array}{l}\text { Health \& safety } \\
\text { awareness }\end{array}$ & 3. & $\begin{array}{l}\text { Quality of } \\
\text { inspections }\end{array}$ & 4. & $\begin{array}{l}\text { Professional } \\
\text { training in } \\
\text { Lean }\end{array}$ \\
\hline 5. & $\begin{array}{l}\text { Many decision } \\
\text { makers }\end{array}$ & 6. & $\begin{array}{l}\text { Role of the } \\
\text { family }\end{array}$ & 7. & $\begin{array}{l}\text { Knowledge } \\
\text { share }\end{array}$ & 8. & Poor Planning \\
\hline 9. & Short-term focus & 10. & $\begin{array}{l}\text { Motivation \& } \\
\text { Reward system }\end{array}$ & 11. & $\begin{array}{l}\text { Promotional } \\
\text { opportunities }\end{array}$ & 12. & $\begin{array}{l}\text { Recruitment } \\
\text { process }\end{array}$ \\
\hline 13. & $\begin{array}{l}\text { Workshop tools } \\
\text { and guidance }\end{array}$ & 14. & $\begin{array}{l}\text { Delay of } \\
\text { processing staff } \\
\text { requests }\end{array}$ & 15. & $\begin{array}{l}\text { Resistance to } \\
\text { change }\end{array}$ & 16. & $\begin{array}{l}\text { Ineffective } \\
\text { Multi-tasking }\end{array}$ \\
\hline 17. & Feedback system & 18. & $\begin{array}{l}\text { Improper } \\
\text { Prioritisation of } \\
\text { tasks }\end{array}$ & 19. & $\begin{array}{l}\text { Performance } \\
\text { indicators }\end{array}$ & 20. & $\begin{array}{l}\text { Contingency } \\
\text { planning }\end{array}$ \\
\hline 21. & $\begin{array}{l}\text { Teamwork \& } \\
\text { leadership attitudes }\end{array}$ & 22. & Job security & 23. & $\begin{array}{l}\text { Aggression on } \\
\text { the shop floor }\end{array}$ & 24. & $\begin{array}{l}\text { Productivity } \\
\text { Monitoring }\end{array}$ \\
\hline 25. & $\begin{array}{l}\text { Cooperation and } \\
\text { mutual trust } \\
\text { between } \\
\text { management } \\
\text { employees }\end{array}$ & 26. & $\begin{array}{l}\text { Bureaucratic } \\
\text { Management } \\
\text { style }\end{array}$ & 27. & $\begin{array}{l}\text { Innovation } \\
\text { management }\end{array}$ & 28. & $\begin{array}{l}\text { Loyalty of the } \\
\text { staff }\end{array}$ \\
\hline 29. & $\begin{array}{l}\text { Research and } \\
\text { development } \\
\text { (R\&D }\end{array}$ & 30. & $\begin{array}{l}\text { Emphasis over } \\
\text { Individual } \\
\text { Contribution }\end{array}$ & 31. & $\begin{array}{l}\text { System of } \\
\text { decision- } \\
\text { making }\end{array}$ & 32. & $\begin{array}{l}\text { Socialisation } \\
\text { of the staff }\end{array}$ \\
\hline 33. & $\begin{array}{l}\text { Emotional } \\
\text { Intelligence of } \\
\text { Managers }\end{array}$ & 34. & $\begin{array}{l}\text { Workload } \\
\text { Pressure }\end{array}$ & 35. & $\begin{array}{l}\text { Ambiguity of } \\
\text { Policies }\end{array}$ & 36. & $\begin{array}{l}\text { Obligatory } \\
\text { work }\end{array}$ \\
\hline 37. & $\begin{array}{l}\text { Identification of } \\
\text { resources }\end{array}$ & & & & & & \\
\hline
\end{tabular}


Table 3 Aspects of Organizational Culture influencing Lean Implementation

\begin{tabular}{|c|c|c|}
\hline No. & $\begin{array}{l}\text { Aspects } \\
\text { of } \\
\text { Organizational } \\
\text { Culture }\end{array}$ & Participants' representation of aspects \\
\hline 1. & $\begin{array}{c}\text { Job } \\
\text { description }\end{array}$ & $\begin{array}{l}\text { The detail of job activities not clearly established among working staff. These unclear } \\
\text { procedural activities directly lead to confusion regarding the correct steps which need to be } \\
\text { taken. }\end{array}$ \\
\hline 2. & $\begin{array}{l}\text { Health \& } \\
\text { safety } \\
\text { awareness }\end{array}$ & $\begin{array}{l}\text { Discusses the methods the health and safety procedures of the organisation. A lack of } \\
\text { awareness of health and safety policies within the workplace has led to poor working } \\
\text { conditions and increased the risk of health hazards. }\end{array}$ \\
\hline 3. & $\begin{array}{l}\text { Quality } \\
\text { inspection }\end{array}$ & $\begin{array}{l}\text { The quality of inspections has not been standardised and hence procedural errors occurred } \\
\text { leading to sporadic delays in implementing Lean. }\end{array}$ \\
\hline 4. & $\begin{array}{l}\text { Profession } \\
\text { al training in } \\
\text { Lean }\end{array}$ & $\begin{array}{l}\text { Employees were unaware of the Lean philosophy, what it aims to achieve and ultimately how } \\
\text { this will be achieved. There is a need to facilitate a professional Lean Training in terms of } \\
\text { workshops / seminars for all staff to realise the advantages and efficiencies of Lean. }\end{array}$ \\
\hline 5. & $\begin{array}{l}\text { Many } \\
\text { decision makers }\end{array}$ & $\begin{array}{l}\text { In the presence of a high number of stakeholders, there is a need to follow protocols. A high } \\
\text { number of tenured employees in middle and senior management roles made decisions based } \\
\text { on their experience, rather than following a company- wide decision-making policy. This } \\
\text { resulted in confusion among several teams and potential errors within the organisation. }\end{array}$ \\
\hline 6. & $\begin{array}{l}\text { Role of } \\
\text { Family }\end{array}$ & $\begin{array}{l}\text { The role of family seemed to influence the work process. When family members were not } \\
\text { involved in the work process, staff could make organised decisions. }\end{array}$ \\
\hline 7. & $\begin{array}{l}\text { Knowledg } \\
\text { e share }\end{array}$ & $\begin{array}{l}\text { Decision making by senior management has remained unquestionable and neither has there } \\
\text { been a culture of dialogue between management and employees. This resulted in knowledge } \\
\text { gap and division among working staff. }\end{array}$ \\
\hline 8. & $\begin{array}{l}\text { Poor } \\
\text { Planning }\end{array}$ & $\begin{array}{l}\text { The organisation regularly wasted too much time in dealing with implementation problems } \\
\text { which could have been foreseen and eliminated with the use of proper planning and past } \\
\text { experiences. }\end{array}$ \\
\hline 9. & $\begin{array}{l}\text { Short - } \\
\text { term focus }\end{array}$ & $\begin{array}{l}\text { Senior management focused their efforts on the short-term accomplishments (weeks/months) } \\
\text { as opposed to long term strategic goals. This has a direct implication for sustainable ROI } \\
\text { (Return on Investment) }\end{array}$ \\
\hline 10. & $\begin{array}{l}\text { Motivatio } \\
\text { n \& Reward } \\
\text { system }\end{array}$ & $\begin{array}{l}\text { The organisation does not have rewards based recognition system to encourage the employees } \\
\text { over performance. The presence of such a rewarding culture in the organisation would } \\
\text { motivate the employees which directly would enhance their productivity. }\end{array}$ \\
\hline 11. & $\begin{array}{l}\text { Promotion } \\
\text { al opportunities }\end{array}$ & $\begin{array}{l}\text { Employees are not given the opportunity to be promoted to middle/ senior management } \\
\text { positions despite their achievements, high performances or even long tenured years of service. }\end{array}$ \\
\hline 12. & $\begin{array}{l}\text { Recruitme } \\
\text { nt process }\end{array}$ & $\begin{array}{l}\text { The employees within the organisation were often unskilled and unexperienced in the work } \\
\text { they were recruited for. This required additional training before they could be placed for } \\
\text { production. }\end{array}$ \\
\hline 13. & $\begin{array}{l}\text { workshop } \\
\text { tools and } \\
\text { guidance }\end{array}$ & $\begin{array}{l}\text { The organisation does not provide its employees with Organizational tools such as handbooks } \\
\text { which can assist in their day to day work procedures and task fulfilments. }\end{array}$ \\
\hline 14. & $\begin{array}{c}\text { Delay of } \\
\text { staff's requests }\end{array}$ & $\begin{array}{l}\text { Due to the high number of management tiers, it takes a long time before requests can be } \\
\text { accepted / rejected }\end{array}$ \\
\hline 15. & $\begin{array}{l}\text { Resistanc } \\
\text { e of change }\end{array}$ & $\begin{array}{l}\text { A behaviour taken by individuals or groups when they observe that a change is happen and } \\
\text { perceived as a threatening to them. }\end{array}$ \\
\hline 16. & $\begin{array}{r}\text { Ineffectiv } \\
\text { e Multi-tasking }\end{array}$ & $\begin{array}{l}\text { Employees within the organisation are given multiple roles and tasks, which causes confusion } \\
\text { and does not allow them to finish their tasks effectively. }\end{array}$ \\
\hline 17. & $\begin{array}{l}\text { Feedback } \\
\text { system }\end{array}$ & $\begin{array}{l}\text { Feedback or evaluation systems are non-existent. If these were available, it would enable } \\
\text { management to understand problems raised by employees. Employees are unable to } \\
\text { understand the impact of decisions made by senior management. }\end{array}$ \\
\hline 18. & $\begin{array}{l}\text { Improper } \\
\text { Prioritisation of } \\
\text { tasks }\end{array}$ & $\begin{array}{l}\text { The sequence of tasks which needs to be completed is unclear and disorderly. Due to this and } \\
\text { other organisational changes employees were unable to achieve the targets set. }\end{array}$ \\
\hline 19. & $\begin{array}{l}\text { Performan } \\
\text { ce indicators }\end{array}$ & $\begin{array}{l}\text { There is no system of recording employee performance, therefore the organisation is unable } \\
\text { to understand and comprehend employee productivity. }\end{array}$ \\
\hline
\end{tabular}




\begin{tabular}{|c|c|c|}
\hline No. & $\begin{array}{l}\text { Aspects } \\
\text { of } \\
\text { Organizational } \\
\text { Culture }\end{array}$ & Participants' representation of aspects \\
\hline 20. & $\begin{array}{l}\text { Contingen } \\
\text { cy planning }\end{array}$ & $\begin{array}{l}\text { The organisation does not have a contingency plan which could guide them in case of an } \\
\text { emergency and thus resume operations. }\end{array}$ \\
\hline 21. & $\begin{array}{l}\text { Teamwor } \\
\mathrm{k} \& \text { leadership } \\
\text { attitude }\end{array}$ & $\begin{array}{l}\text { The different functions within the organisation have their own individual plans, without } \\
\text { communicating their plan with other departments, rather than working as an effective team. }\end{array}$ \\
\hline 22. & $\begin{array}{l}\text { Job } \\
\text { security }\end{array}$ & There is no guarantee of job security despite an employee's best efforts. \\
\hline 23. & $\begin{array}{l}\text { Aggressio } \\
\mathrm{n} \text { to the shop } \\
\text { floor }\end{array}$ & $\begin{array}{l}\text { Due to the hierarchical nature of the organisation, senior management are aggressive in } \\
\text { directing their lower ranking employees. }\end{array}$ \\
\hline 24. & $\begin{array}{l}\text { Productivi } \\
\text { ty Monitoring }\end{array}$ & $\begin{array}{l}\text { Productivity was not measured other than recorded daily tasks and ability to meet deadlines. } \\
\text { The key reason for poor productivity was related to lack of motivation by the employees. }\end{array}$ \\
\hline 25. & $\begin{array}{l}\text { Cooperati } \\
\text { on and mutual } \\
\text { trust between } \\
\text { management } \\
\text { employees }\end{array}$ & $\begin{array}{l}\text { Lack of reputability such as not taking ownership of tasks and not executing within allocated } \\
\text { time prevailed. This lead to working inefficiencies. Employees do not feel safe to share their } \\
\text { inner believes or feeling with senior management as they fear they will receive negative } \\
\text { feedback. Senior management are unreceptive to ideas/improvements which have been put } \\
\text { forward by junior employees. }\end{array}$ \\
\hline 26. & $\begin{array}{l}\text { Bureaucra } \\
\text { tic Management } \\
\text { style }\end{array}$ & $\begin{array}{l}\text { Management style followed a rigid structure in dealing with employees by not accounting the } \\
\text { personal factors relative to individual employees. Rather, a rigid structure was applied to all } \\
\text { working staff regardless of individual circumstances. }\end{array}$ \\
\hline 27. & $\begin{array}{r}\text { Innovatio } \\
\text { n management }\end{array}$ & $\begin{array}{l}\text { The top management has not held any initiatives to develop innovation nor thought to } \\
\text { implement any in the road map. This may lead to critical issues for future sustenance. }\end{array}$ \\
\hline 28. & $\begin{array}{l}\text { Loyalty of } \\
\text { the staff }\end{array}$ & $\begin{array}{l}\text { Most of the employees displayed no sign of loyalty to the organisations. They were primarily } \\
\text { driven by the work and pay system which was mechanical. }\end{array}$ \\
\hline 29. & $\begin{array}{l}\text { Research } \\
\text { and } \\
\text { development } \\
(\mathrm{R} \& \mathrm{D})\end{array}$ & $\begin{array}{l}\text { There has been neither support nor interest from the top management in investing into R\&D } \\
\text { activities that lead to a sustainable future of the organisation. The organisation carried a } \\
\text { unidimensional strategy. }\end{array}$ \\
\hline 30. & $\begin{array}{l}\text { Emphasis } \\
\text { over Individual } \\
\text { Contribution }\end{array}$ & $\begin{array}{l}\text { Focus on Individual contribution was seen to be lacking and a result key factors such as } \\
\text { capabilities, Lean \& Development, and productivity were ignored. Supporting the employee } \\
\text { to increase the capability of knowledge. }\end{array}$ \\
\hline 31. & $\begin{array}{l}\text { System of } \\
\text { decision- } \\
\text { making }\end{array}$ & $\begin{array}{l}\text { Design a management system to produce orders and decisions to identify, solve problems and } \\
\text { make decisions. }\end{array}$ \\
\hline 32. & $\begin{array}{l}\text { Socialisati } \\
\text { on of the staff }\end{array}$ & $\begin{array}{l}\text { Many Employees lacked social knowledge and inter-personal skills which are required to } \\
\text { foster a healthy professional environment. Most of the employees were only concerned with } \\
\text { work and pay. }\end{array}$ \\
\hline 33. & $\begin{array}{l}\text { Emotional } \\
\text { Intelligence of } \\
\text { Managers }\end{array}$ & $\begin{array}{l}\text { How to monitor other people's emotion, thinking and behaviour. It is the ability to recognize } \\
\text { and deal with other people emotion effectively; it is basically putting the self in the shoes of } \\
\text { others. Understanding of the context and having awareness of others. Lack of emotional } \\
\text { support from managers was prevalent. In order to understand emotions, thought processes and } \\
\text { behaviour of staff, it is important for managers to have the ability to recognize and deal with } \\
\text { other people effectively. }\end{array}$ \\
\hline 34. & $\begin{array}{l}\text { workload } \\
\text { Pressure }\end{array}$ & $\begin{array}{l}\text { Daily routine of same kind of work along with orders to finish within deadlines from } \\
\text { supervisors has resulted in creating additional pressure for the employees. This lead to pileup } \\
\text { of stress at work. This could be eased with the help of recreational activities. }\end{array}$ \\
\hline 35. & $\begin{array}{l}\text { Ambiguit } \\
\mathrm{y} \text { of Policies }\end{array}$ & $\begin{array}{l}\text { Reliable information about the performance, governance, value and risks of all information } \\
\text { related to the employee }\end{array}$ \\
\hline 36. & $\begin{array}{l}\text { Obligator } \\
\text { y work }\end{array}$ & $\begin{array}{l}\text { The environment that prevailed in the organisations was that of an enforceable culture rather } \\
\text { than a proactive culture. Instead of constructive criticism and supportive directions, employees } \\
\text { were often commanded and reminded of their duties. }\end{array}$ \\
\hline 37. & $\begin{array}{r}\text { Identificat } \\
\text { ion of resources }\end{array}$ & lired and provide the right information related to work. \\
\hline
\end{tabular}


Table 4 Themes developed

\begin{tabular}{|c|c|c|c|}
\hline $\begin{array}{l}\text { Higher level } \\
\text { theme }\end{array}$ & $\begin{array}{l}\text { Aspects } \\
\text { code }\end{array}$ & $\begin{array}{l}\text { Aspects grouped together } \\
\text { into higher level }\end{array}$ & $\begin{array}{l}\text { Participants statements used to describe } \\
\text { the higher-level theme }\end{array}$ \\
\hline $\begin{array}{l}\text { Communication } \\
\& \text { interaction in } \\
\text { the organisation }\end{array}$ & $\begin{array}{l}5 \\
7 \\
14 \\
16 \\
34\end{array}$ & $\begin{array}{l}\text { Many decision makers } \\
\text { Knowledge share } \\
\text { Delay of staff's requests } \\
\text { Ineffective } \\
\text { Workload Pressure }\end{array}$ & $\begin{array}{l}\text { Convoy your massage to other personal or } \\
\text { a group. Thus, the employees know } \\
\text { exactly what is important, who is supposed } \\
\text { to do what and when. Communication } \\
\text { among the staff climate formal and } \\
\text { informal information flows in time for } \\
\text { inquiry and reflection use of humour and } \\
\text { many other languages. }\end{array}$ \\
\hline $\begin{array}{l}\text { Organisation's } \\
\text { Strategy and } \\
\text { vision }\end{array}$ & $\begin{array}{l}8 \\
9 \\
18 \\
35 \\
31 \\
6\end{array}$ & $\begin{array}{l}\text { Poor Planning } \\
\text { Short -term focus } \\
\text { Improper Prioritisation of } \\
\text { tasks } \\
\text { Ambiguity of Policies } \\
\text { System of decision-making } \\
\text { Role of Family }\end{array}$ & $\begin{array}{l}\text { An essential factor which influences } \\
\text { different control system configuration and } \\
\text { operational environment change. Identify } \\
\text { tactics and roadmap to achieve the mission } \\
\text { of the organization. Generate an objective } \\
\text { to align the managerial practices process } \\
\text { with their strategies priorities to improve } \\
\text { their performance, system of decision } \\
\text { making and to apply in the organization. }\end{array}$ \\
\hline $\begin{array}{l}\text { Organisation's } \\
\text { Infrastructure of } \\
\text { the workshop }\end{array}$ & $\begin{array}{l}2 \\
13\end{array}$ & $\begin{array}{l}\text { Health \& safety awareness } \\
\text { Workshop tools and guidance }\end{array}$ & $\begin{array}{l}\text { This theme refers to the structure of the } \\
\text { organization around the employee. Easily } \\
\text { for employees to move with security } \\
\text { around within the confinements of their } \\
\text { workplace. Poor Infrastructure planning } \\
\text { was evident from the layout of the } \\
\text { workshop. Ineffective planning resulted in } \\
\text { redundant activities and procedures } \\
\text { indicating a re-design of workshop layout } \\
\text { to complement Lean. }\end{array}$ \\
\hline $\begin{array}{l}\text { Quality risk } \\
\text { management }\end{array}$ & $\begin{array}{l}3 \\
19 \\
20 \\
29\end{array}$ & $\begin{array}{l}\text { Quality inspection } \\
\text { Performance indicators } \\
\text { Contingency planning } \\
\text { Research \& development } \\
\text { (R\&D) }\end{array}$ & $\begin{array}{l}\text { A group of business process, technology } \\
\text { capabilities and operation environment to } \\
\text { create a collaborative program to } \\
\text { identifying mitigating product, } \\
\text { quantifying, operational risks that can be } \\
\text { impact quality. }\end{array}$ \\
\hline Human Recourse & $\begin{array}{l}11 \\
12 \\
22 \\
17\end{array}$ & $\begin{array}{l}\text { Job description } \\
\text { Motivation and reward system } \\
\text { Promotional opportunities } \\
\text { Recruitment process } \\
\text { Job security } \\
\text { Feedback system }\end{array}$ & $\begin{array}{l}\text { This them refer to the employees' issues. It } \\
\text { is a set of role related to the employee, } \\
\text { describing their duty. Determine the needs } \\
\text { of the employee and recruit best } \\
\text { employees. Dealing with performance and } \\
\text { trouble issues. Pushing the employees to } \\
\text { the best in their job. }\end{array}$ \\
\hline $\begin{array}{c}\text { Change } \\
\text { management and } \\
\text { behaviour } \\
\text { patterns }\end{array}$ & $\begin{array}{l}21 \\
23 \\
36 \\
26 \\
15\end{array}$ & $\begin{array}{l}\text { Teamwork \& leadership } \\
\text { attitude } \\
\text { Aggression to the shop floor } \\
\text { Obligatory work } \\
\text { Bureaucratic Management } \\
\text { Resistance to change }\end{array}$ & $\begin{array}{l}\text { Approach to transitioning group, team and } \\
\text { organization using tactics to re-direct the } \\
\text { use of organization system process, } \\
\text { resources, organization environment, the } \\
\text { reaction of the employees or any other } \\
\text { method in the operation that } \\
\text { reshape effectively the organization. }\end{array}$ \\
\hline $\begin{array}{c}\text { Sustain } \\
\text { continuous } \\
\text { improvement }\end{array}$ & $\begin{array}{l}25 \\
28 \\
33 \\
30 \\
27 \\
37\end{array}$ & $\begin{array}{l}\text { Cooperation and mutual trust } \\
\text { between employees. } \\
\text { Loyalty of the staff } \\
\text { Emotional Intelligence of } \\
\text { managers } \\
\text { Emphasis on the Individual } \\
\text { contribution } \\
\text { Innovation management. } \\
\text { Identification of resources }\end{array}$ & $\begin{array}{l}\text { keep going or to keep up to improve the } \\
\text { employee and process performance to be } \\
\text { continually monitored. Focusing to } \\
\text { increase the capabilities, efficiency and the } \\
\text { effectiveness to achieve its objectives. } \\
\text { Identify the opportunity for streaming } \\
\text { work. Many employees in the top } \\
\text { management were aware of the prevailing } \\
\text { gap in the organisation at various functions }\end{array}$ \\
\hline
\end{tabular}




\begin{tabular}{l|l|l|l}
\hline $\begin{array}{l}\text { Higher level } \\
\text { theme }\end{array}$ & $\begin{array}{l}\text { Aspects } \\
\text { code }\end{array}$ & $\begin{array}{l}\text { Aspects grouped together } \\
\text { into higher level }\end{array}$ & $\begin{array}{l}\text { Participants statements used to describe } \\
\text { the higher-level theme }\end{array}$ \\
\hline & 32 & $\begin{array}{l}\text { Socialisation of the staff } \\
\text { Professional training in Lean }\end{array}$ & $\begin{array}{l}\text { of engagements such as operations, human } \\
\text { relations, and productions. }\end{array}$ \\
& 4 & Productivity Monitoring & \\
\hline
\end{tabular}




\begin{tabular}{|c|c|c|c|}
\hline Theme & Ideal position from literature review & References & Ideal position from participants \\
\hline $\begin{array}{l}\text { Communication \& } \\
\text { interaction in the } \\
\text { organisation }\end{array}$ & $\begin{array}{l}\text { Communication in the workplace with employees as } \\
\text { the backbone for every activity, and communication is } \\
\text { highly appreciated, established formal ways in which } \\
\text { to promote communication, such as using technology, } \\
\text { table Conferences, and various subcommittees, as well } \\
\text { as establishing a hotline that employees can use to } \\
\text { complain if they face problems }\end{array}$ & $\begin{array}{l}\text { Wong et al., 2009; Timans et al., 2011; } \\
\text { Chandler and Hanks, 1994; Toyota, 2005; } \\
\text { Takeuchi et al., 2008, p. 100; Boyle and } \\
\text { Scherrer-Rathje, 2009; Furlan, Vinelli and Dal } \\
\text { Pont, 2011; Nordin et al., 2012; Papadopoulou } \\
\text { and Özbayrak, 2005; Rose et al., 2011; Sim and } \\
\text { Rogers, 2008; Worley and Doolen, } 2006\end{array}$ & $\begin{array}{l}\text { The employees and the managers } \\
\text { have a good interaction between } \\
\text { them. They communicate with each } \\
\text { other to know exactly what is } \\
\text { important, who is supposed to do } \\
\text { what and when. Communication } \\
\text { flows perfectly to fulfil the employee } \\
\text { needs. }\end{array}$ \\
\hline $\begin{array}{c}\text { Organisation's Strategy } \\
\text { and vision }\end{array}$ & $\begin{array}{l}\text { Have a managemet involvement and leadership } \\
\text { commitment in order to succeed in its long term } \\
\text { journay, customer relations; people (in terms of skills, } \\
\text { training, empowerment, and involvement); } \\
\text { communication (including teamwork and } \\
\text { communication between people and between } \\
\text { departments); motivation (empowerment, reward and } \\
\text { recognition); financial capabilities; HR (practising } \\
\text { teamwork and shared vision with employees) and and } \\
\text { process quality provided by clear organization } \\
\text { strategy and vision }\end{array}$ & $\begin{array}{l}\text { Löfving, Säfsten and Winroth, 2014a; Platts et } \\
\text { al., 1996; Skinner, 1969; Platts, 1994; Coch and } \\
\text { French, 1948; Riis, at el. 2006; Slack, 2015; } \\
\text { Achanga et al., 2006d, 2012b; AL-Najem et al., } \\
\text { 2013; Al-Najem, Dhakal and Bennett, 2012; } \\
\text { Bakås, Givaert and Van Landeghem, 2011; } \\
\text { Banuelas Coronado and Antony, 2002; Holland } \\
\text { and Light, 1999; Löfving, Säfsten and Winroth, } \\
\text { 2014b; Pakdil and Leonard, 2015b;Cooper, } \\
1999\end{array}$ & $\begin{array}{l}\text { The organization has a good } \\
\text { planning, tactics and road map to } \\
\text { achieve the goals of the organization } \\
\text { for a long-term focus. The sequences } \\
\text { of the tasks are undertaken in an } \\
\text { appropriate way. The policies within } \\
\text { the organization are clear. A good } \\
\text { system of decision making exists and } \\
\text { is applied in the organization. }\end{array}$ \\
\hline $\begin{array}{c}\text { Organisation's } \\
\text { Infrastructure of the } \\
\text { workshop }\end{array}$ & $\begin{array}{l}\text { The infrastructure within SMEs workshop provide } \\
\text { with safety and health guide and allows effective } \\
\text { communication channels across all aspects of the } \\
\text { organization, the resources made available to the team } \\
\text { and the management style in which the team operate }\end{array}$ & $\begin{array}{l}\text { Boyer ,1996; Mittal et al. 2011; Bhamra et al., } \\
\text { 2011; Baidoun, 2004; Alsmadi, at el.2012b; } \\
\text { Laureani and Antony, 2016; McLaughlin, } \\
\text { 2016; K. Dibia, at el. 2014; Soriano-Meier and } \\
\text { Forrester ,2002; Longoni et al., 2013; Eklund } \\
\text {,2000a }\end{array}$ & $\begin{array}{l}\text { The buildings and support areas are } \\
\text { appropriate for employees' } \\
\text { requirements. The employee } \\
\text { functions within his facility } \\
\text { effectively. The structure of the } \\
\text { organization around the employee is } \\
\text { provided to ensure safety. There is } \\
\text { guidance for all equipment. The } \\
\text { organization provides appropriate } \\
\text { facilities for employees (rest rooms, }\end{array}$ \\
\hline
\end{tabular}




\begin{tabular}{|c|c|c|c|}
\hline Theme & Ideal position from literature review & References & Ideal position from participants \\
\hline & & & $\begin{array}{l}\text { room for smoking and a coffee shop, } \\
\text { etc.). }\end{array}$ \\
\hline Quality risk management & $\begin{array}{l}\text { Achieving excellent quality with minimum utilization } \\
\text { of resources and cost with applying feedback system } \\
\text { is ultimate purpose and achieved, the risks should be } \\
\text { identified, analysed, treated and monitored, } \\
\text { significant progress in increasing productivity, } \\
\text { product quality while lowering product lead times, } \\
\text { Increased variety of products, Increased flexibility of } \\
\text { manufacturing operations, encourage employees to } \\
\text { develop a sense of responsibility for quality and helps } \\
\text { to reduce workplace health and safety risks }\end{array}$ & $\begin{array}{l}\text { Vincent, 1997; Crema and Verbano, 2015; } \\
\text { Verbano and Turra, 2010; Jadhav et al., 2015; } \\
\text { Camuffo,at el, 2017;Salem and Zimmer, 2005; } \\
\text { Womack, at el, 1990; Salem and Zimmer, } \\
\text { 2005; Waldman et al., 1998; Gijo, 2011; } \\
\text { McLean, at el 2017; Halling, 2013; Eklund } \\
\text {,2000 }\end{array}$ & $\begin{array}{l}\text { The organization operates } \\
\text { systematically to achieves the goals } \\
\text { of the business process, technology } \\
\text { capabilities and operation } \\
\text { environment in a collaborative way, } \\
\text { identifying risks, taking appropriate } \\
\text { actions to move or mitigate those } \\
\text { risks. }\end{array}$ \\
\hline Human Recourse & $\begin{array}{l}\text { The employees are well trained to foster improvement } \\
\text { and knowledge share. Motivation are provided to } \\
\text { encourage people to participate and provide new } \\
\text { ideas; worker is highly rewarded for their efforts, } \\
\text { Employee empowerment and involvement in lean } \\
\text { implantation as the key success factor as the focus is } \\
\text { on "teamwork, }\end{array}$ & $\begin{array}{l}\text { Naor et al., 2008;(AL-Najem et al., 2013; } \\
\text { Alagaraja, 2014; Camuffo, De Stefano and } \\
\text { Paolino, 2017; Dartey-Baah, 2013b; Jeyaraman } \\
\text { and Kee Teo,2010; Kovacheva, 2010; Lorden } \\
\text { et al., 2014; Nolan and Garavan, 2015; } \\
\text { Panizzolo et al., 2012b; Panizzolo, Bernardel } \\
\text { and Biazzo, 2014; Zargun and Al-Ashaab, } \\
\text { 2013; Hahn et al., 1999; Laureani and Antony, } \\
\text { 2016a; Arnaud and Wasieleski, 2014; } \\
\text { Camuffo, at el, 2017; Kochan, at el. 1997; } \\
\text { MacDuffie and Helper, } 1997\end{array}$ & $\begin{array}{l}\text { The Human Resources department is } \\
\text { updated with the employees' needs. } \\
\text { The Human Resources department } \\
\text { evaluate candidate's capabilities to } \\
\text { ensure they can meet business } \\
\text { requirements. The Human Resources } \\
\text { department manage performance and } \\
\text { solve job issues to allow employees } \\
\text { to perform effectively. }\end{array}$ \\
\hline $\begin{array}{l}\text { Change management and } \\
\text { behaviour patterns }\end{array}$ & $\begin{array}{l}\text { The employee attitude towards change are flexible, the } \\
\text { leadership style is primarily concern with the } \\
\text { capabilities required enact change successfully, } \\
\text { ensures the personal property is aligned with the } \\
\text { business strategy, technology, and business process of }\end{array}$ & $\begin{array}{l}\text { Gupta, Acharya and Patwardhan, 2013;Fok- } \\
\text { yew and Ahmad, 2014; Bamber and Dale, } \\
\text { 2000b; Boyle and Scherrer-Rathje, 2009; } \\
\text { Karlsson and Âhlström, 1996; Lewchuk, } \\
\text { Stewart and Yates, 2001; Motwani, 2003; }\end{array}$ & $\begin{array}{l}\text { The organization's management is } \\
\text { aware of the change strategy and take } \\
\text { appropriate action to ensure the } \\
\text { strategy is achieved. Management is } \\
\text { flexible with the workflow to allow }\end{array}$ \\
\hline
\end{tabular}




\begin{tabular}{|c|c|c|c|}
\hline Theme & Ideal position from literature review & References & Ideal position from participants \\
\hline & $\begin{array}{l}\text { the company, contribute to teamwork building, cross- } \\
\text { functional movement, information transparency } \\
\text {,participative management, teamwork rewarding, } \\
\text { open communication and information sharing, } \\
\text { knowledge learning and sharing, autonomous } \\
\text { leadership and decentralised responsibilities }\end{array}$ & $\begin{array}{l}\text { Nordin et al., 2012; Sun et al., 2006; Worley } \\
\text { and Doolen, 2006; Lathin ; Hall ,1995 and } \\
\text { Lathin and Mitchell ,2001; K. Dibia, Nath } \\
\text { Dhakal and Onuh, 2014; De Treville and } \\
\text { Antonakis, 2006; Wahjudi et al., 2016; de } \\
\text { Treville and Antonakis, } 2006\end{array}$ & $\begin{array}{l}\text { the employees autonomy in } \\
\text { achieving their objectives. } \\
\text { Leadership and team spirit are } \\
\text { applied within the organization in a } \\
\text { professional way. Respect and self- } \\
\text { esteem are shown to all employees. }\end{array}$ \\
\hline $\begin{array}{c}\text { Sustain continuous } \\
\text { improvement }\end{array}$ & $\begin{array}{l}\text { All employees are involved in each task. Top } \\
\text { management creative keeping them excited about the } \\
\text { tasks in workshop. The employees recognize that } \\
\text { leaders are interested in their opinions and they are } \\
\text { allowed to put their own ideas into practical and make } \\
\text { their lob better, every worker from the top levels to the } \\
\text { bottom must feel able to bring new ideas to the table, } \\
\text { which forces people to give maximum effort, } \\
\text { innovative thinking and developing teams and } \\
\text { individuals }\end{array}$ & $\begin{array}{l}\text { Testani and Ramakrishnan, 2012; Albliwi et } \\
\text { al., 2014b; Bessant and Caffyn, 1997; Fryer, } \\
\text { Antony and Douglas, 2007; K. Dibia, Nath } \\
\text { Dhakal and Onuh, 2014; Laureani and Antony, } \\
\text { 2016b; McLean, Antony and Dahlgaard, 2017; } \\
\text { Sanchez and Blanco, 2014; Singh and Singh, } \\
\text { 2012; Womack, J., \& Jones, 2003; Yan-jiang, } \\
\text { Lang and Xiao-na, 2006; Al-najem, 2014; } \\
\text { Takeuchi, at el. 2008; Radeka, 2009; Takeuchi } \\
\text { et al., } 2008\end{array}$ & $\begin{array}{l}\text { The organization continuously works } \\
\text { to improve the employee and process } \\
\text { performance. The organization } \\
\text { focuses on increasing capabilities, } \\
\text { efficiency and effectiveness. The } \\
\text { organization continually strives to } \\
\text { improve cooperation between various } \\
\text { functions such as operations, human } \\
\text { relations and productions. }\end{array}$ \\
\hline
\end{tabular}


Table 6 Organizational Culture assessment scoring result

\begin{tabular}{ll}
\hline Theme & Average score \\
\hline Communication \& interaction in the organisation & 3.85 \\
\hline Organisation's Strategy and vision & 2.98 \\
\hline Organisation's Infrastructure of the workshop & 4.22 \\
\hline Quality risk management & 4.8 \\
\hline Human Recourse & 3.71 \\
\hline Change management and behaviour patterns & 2.53 \\
\hline Sustain continuous improvement & 2.72 \\
\hline
\end{tabular}




\section{FRAMEWORK TO FACILITATE LEAN IMPLEMENTATION}

\section{Knowledge management and} share system

- Computer networks.

- Database and electronic bulletin boards and discussion groups

- Create a forum and an electronic community of practice that facilitates contact between the person seeking knowledge and those who may have access to the knowledge.

- Face-to-face communication and meeting which leads to transferring of knowledge

\section{Managing family influences}

- Conducting a review board to separate family member's Interfering within the whole organization process. Managing the family influence will create a climate of lean culture.
Health and safety climate

- Written statement of policy required, policy is used in relation to health and safety

- Meeting of important health and safety procedures or lessons from a recent accident and chairing meetings of the central health and safety committee.

- Document for conciseness and are intended to include the safety, health and others at work due to work activities

- Auditing and reviewing for health and safety climate
Training and education to increase knowledge of lean

- Training needs for employees related to the work

- Assessed to identify skills or abilities that the employee will have to possess to grow into future positions.

- Observation employee performance.

\section{External input}

- Visits other manufacturing firm as an external source for lean implementation process for ideas

- Investments in consultancy and hiring experts to improve the work

of
tancy
prove

(
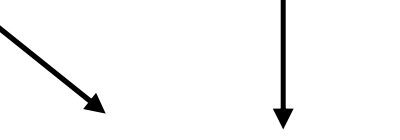

LEAN CULTURE
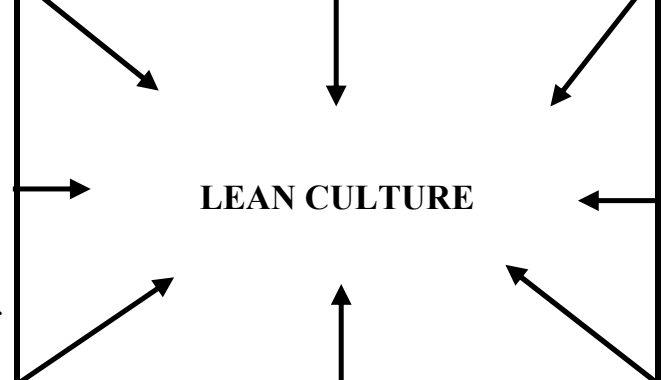

Top management and leadership commitment

- knowing people's capabilities

- Managing talent people

- Providing training

- Rewarding system

- Motivation to encourage people to participate and provide new ideas
- Investment in consultants and expertise.

- Managing family influences.

- Allocating resources to creativity and innovative capability of employees

- Employee involvement

- Leadership involve in day-today operations.

- Fairness at work to create trust between senior management and shop floor workers.

- Job rotation to gaining knowledge for the whole process
Feedback system

- Regular feedback to workers on the current processes, defect rates, machine breakdowns, etc.,

- visible meeting such as face to face to help improve the relationship among the employee and avoid mistakes.

- Feedback questionnaire and survey for each month.

\section{Recruitment and selection process}

- A realistic job preview providing information about what it will be like to work in such situations

- Team member involvement in a selection process oriented to potential and process skills of recruits can facilitate a participative climat.

- The family owners of the business should not be joined

- Focus group activity to identify the talent, leadership people 
Table 8 Criteria for ensuring rigour in qualitative research (Liamputtong, 2009)

\begin{tabular}{|c|c|c|c|}
\hline Rigour critical & Criteria for rigour & Research strategy & Techniques to insure rigour \\
\hline \multirow{6}{*}{ Credibility } & \multirow{6}{*}{ Truth value } & & Purposeful/theoretical sampling \\
\hline & & Field notes/memo & Negative/deviant case \\
\hline & & Tape recorder & Constant comparison \\
\hline & & Thematic log & Member checking \\
\hline & & Auditing transcript & Triangulation \\
\hline & & & Audit trial \\
\hline \multirow{2}{*}{ Transferability } & \multirow{2}{*}{ Applicability } & Data display & Purposeful/theoretical sampling \\
\hline & & Simultaneous literature review & Thick description \\
\hline \multirow{6}{*}{ Dependability } & \multirow{6}{*}{ Consistency } & Field notes/memo & \\
\hline & & Tape recorder & Negative/deviant case \\
\hline & & Thematic log & Member checking \\
\hline & & Auditing transcript & Triangulation \\
\hline & & Researcher's story & Audit trial \\
\hline & & Reflexivity & \\
\hline Confirmability & Neutrality & Filed notes/ memo & Audit trial \\
\hline
\end{tabular}


Table 9 Inter-rate reliability result

\begin{tabular}{|c|c|c|c|c|c|}
\hline No & Interview & Rater 1 & Rater 2 & Kappa & $\%$ \\
\hline 1 & Interview No. 7 & 33 & 31 & 0.72 & $94 \%$ \\
\hline 2 & Interview No. 8 & 30 & 29 & 0.78 & $97 \%$ \\
\hline 3 & Interview No. 17 & 46 & 45 & 0.79 & $98 \%$ \\
\hline 4 & Interview No. 18 & 49 & 49 & 1.00 & $100 \%$ \\
\hline 5 & Interview No. 25 & 39 & 38 & 0.79 & $97 \%$ \\
\hline 6 & Interview No. 30 & 43 & 42 & 0.79 & $98 \%$ \\
\hline 7 & Interview No. 2 & 24 & 23 & 0.34 & $96 \%$ \\
\hline 8 & Interview No. 4 & 50 & 48 & 0.65 & $96 \%$ \\
\hline 9 & Interview No. 13 & 27 & 25 & 0.63 & $93 \%$ \\
\hline 10 & Interview No. 5 & 39 & 38 & 0.79 & $97 \%$ \\
\hline 11 & Interview No. 27 & 39 & 38 & 0.79 & $97 \%$ \\
\hline \multirow[t]{2}{*}{12} & Interview No. 11 & 30 & 28 & 0.64 & $93 \%$ \\
\hline & Average & & & 0.73 & $96 \%$ \\
\hline
\end{tabular}




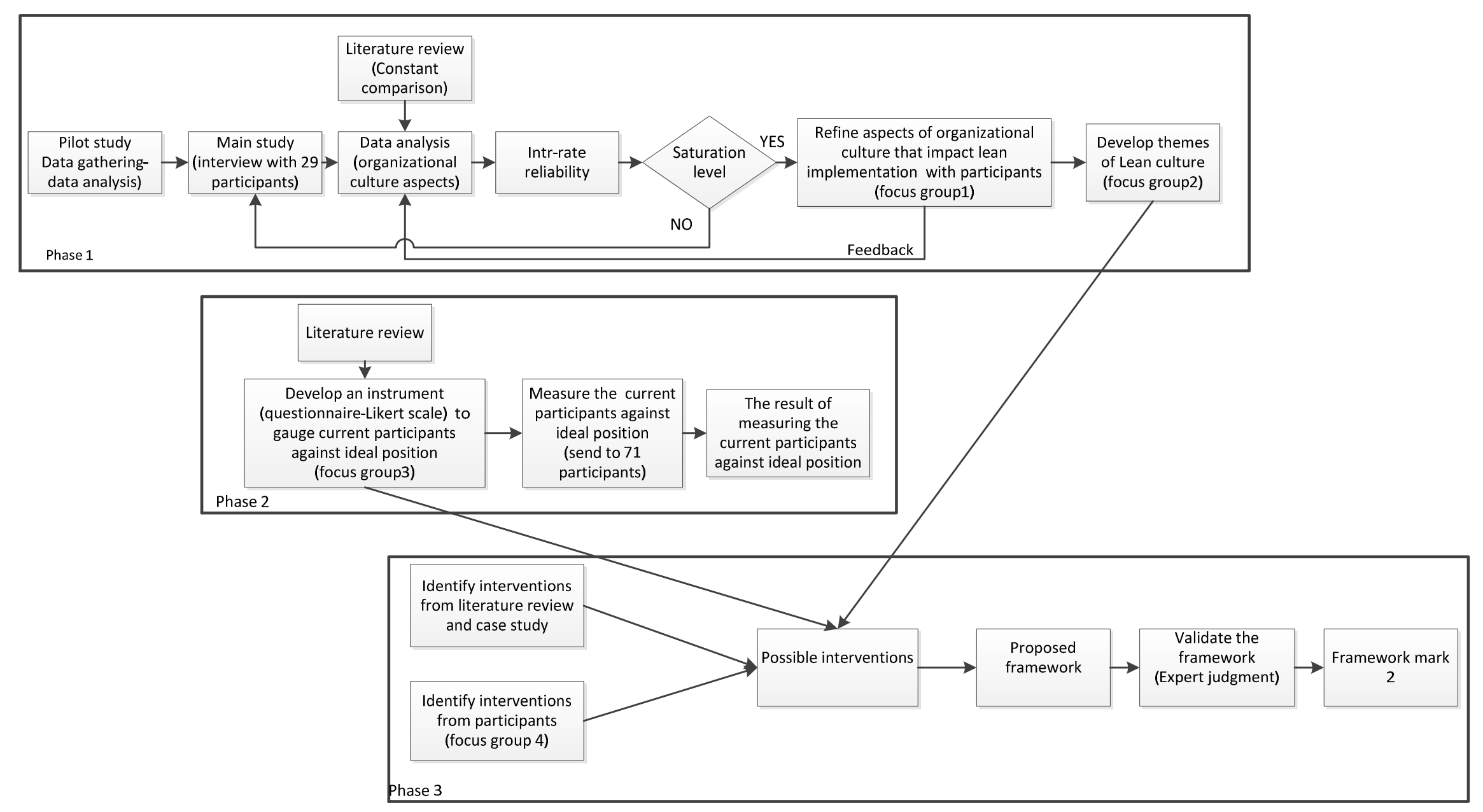

Figure 1 Research Process Phases 


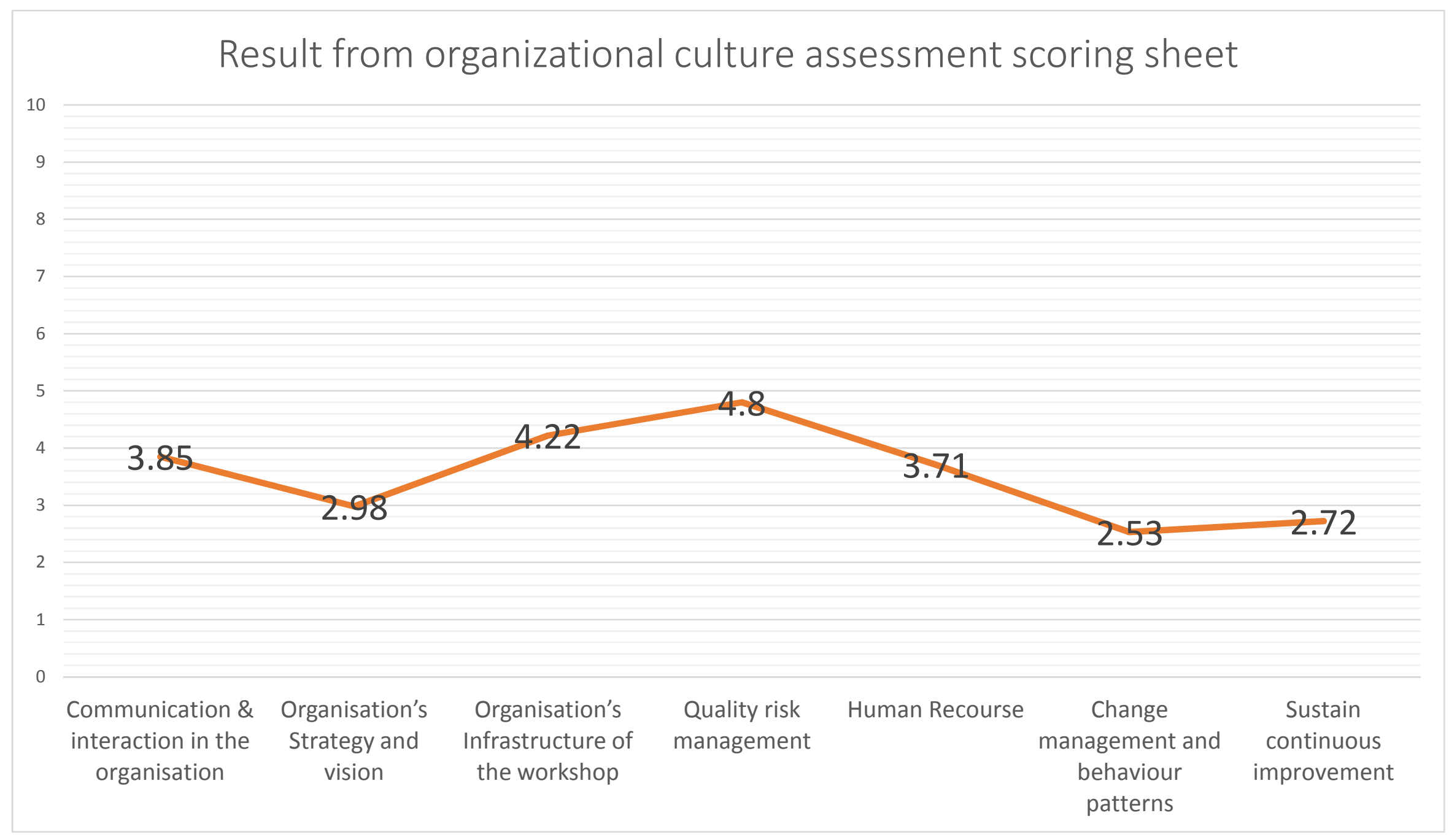

Figure 2 Result from Organizational Culture assessment scoring sheet 
2019-06-26

\title{
A framework to improve lean
} implementation by review leveraging aspects of organizational culture: The case of Saudi Arabia

\author{
Alkhoraif, Abdullah
}

Inderscience

Alkhoraif A, McLaughlin P, Rashid H. (2019) A framework to improve lean implementation by review leveraging aspects of organizational culture: The case of Saudi Arabia, International Journal of Agile Systems and Management, Volume 12, Issue 2, 2019, pp. 124-179

https://doi.org/10.1504/IJASM.2019.100357

Downloaded from Cranfield Library Services E-Repository 